\title{
Performance of an activated sludge followed by membrane process (AS-MP) treating simulated industrial wastewaters: effects of operating factors and feed characteristics
}

\author{
S. Rahimi ${ }^{1} \cdot$ A. A. Zinatizadeh ${ }^{1,2}\left(\right.$ D $\cdot$ P. Mohammadi ${ }^{3} \cdot$ S. Zinadini $^{1} \cdot$ A. Asadi $^{4}$
}

Received: 4 May 2018 / Accepted: 23 July 2020 / Published online: 5 August 2020

(c) The Author(s) 2020

\begin{abstract}
The main aim of the present study is to determine the optimum operating conditions for different feed compositions with less irreversible membrane fouling in an activated sludge followed by membrane process (AS-MP). In this regard, three different wastewaters with different $\mathrm{BOD}_{5} / \mathrm{COD}$ ratios ( 0.83 for soft drink, 0.63 for pineapple fruit juice and 0.36 for amoxicillin) as an index of biodegradability were selected. The AS-MP system was operated with biomass concentration of 7000-8000 mg/l and different hydraulic retention times (HRTs) in the range of 4-20 h. The optimal HRT was decreased as $\mathrm{BOD}_{5} / \mathrm{COD}$ ratio was increased. In order to investigate fouling behavior of membranes in the AS-MP, a commercial polyvinylidene fluoride (PVDF) microfiltration (MF) membrane and high-performance synthetic $\mathrm{ZnFe}_{2} \mathrm{O}_{4} / \mathrm{SiO}_{2}$ embedded polyether sulfone (PES) ultrafiltration (UF) membrane were applied. As a result, the UF membrane indicated the highest flux recovery ratio (FRR) for pineapple fruit juice wastewater relative to the other wastewaters. Soft drink wastewater had the maximum permeability and FRR for MF membrane due to low turbidity of the feed and low interaction with MF membrane composition, whereas this wastewater showed a lower permeability and FRR in the UF membrane, implying an effective interaction between the residual soluble microbial products and the UF membrane composition. Both membranes showed almost the same performance for amoxicillin wastewater.
\end{abstract}

Keywords Activated sludge, membrane process $\cdot \mathrm{MF}$ and UF membranes $\cdot$ Membrane fouling $\cdot \mathrm{BOD}_{5} / \mathrm{COD}$ ratios

\section{Introduction}

Industrial wastewater is one of the significant sources of environment pollution that wastewater treatment should be designed especially for the particular type of produced effluent (Shi and Qian 2009). Numerous treatment methods such as biological systems (Pirsaheb et al. 2015; Amini et al.

A. A. Zinatizadeh

zinatizadeh@razi.ac.ir

1 Environmental Research Center (ERC), Department of Applied Chemistry, Razi University, Kermanshah, Iran

2 Department of Environmental Sciences, University of South Africa, Pretoria, South Africa

3 Department of Environmental Health Engineering, Public Health Faculty, Kermanshah University of Medical Science, Kermanshah, Iran

4 Department of Gas and Petroleum, Yasouj University, 75918-74831 Gachsaran, Iran
2013; Asadi et al. 2012a, b; Pirsaheb et al. 2009), photocatalytic degradation (Shahrezaei et al. 2012), coagulation and electrocoagulation (Abbasi et al. 2020; Zinatizadeh et al. 2017; Birjandi et al. 2013), adsorption process (Sharafi et al. 2015) and membrane technology (Gholami et al. 2018; Zinadini et al. 2017; Rahimi et al. 2016; Abou-Elela and ElKhateeb 2015) have been used to remove pollutants from different industrial effluents. Besides, natural treatment systems have been extensively studied for wastewater treatment as a cost-effective process, although their retention time is relatively long due to weak energy dissipation (Mansouri et al. 2012).

Among biological treatment systems used, some are conventionally applied including activated sludge (AS), trickling filter (TF), rotating biological contactor (RBC), fluidized bed bioreactor (FBBRs), biological nutrient removal (BNR), membrane bioreactors (MBRs) (Grady et al. 1999). MBR is a wastewater treatment technology combining membrane separation process with conventional activated sludge (CAS) treatment process that can be used for producing high 
quality effluent (Stephenson et al. 2000). Some of the advantages of MBR are high biomass concentrations, less space requirement rather than traditional systems, lower hydraulic retention time, lower biosolids, high effluent quality, good disinfection capability and higher volumetric loading (Shon et al. 2011).

Microfiltration (MF) and ultrafiltration (UF) are two types of membrane processes that expansively used in MBR (Ho and Sirkar 2012). UF takes away all microbiological species deleted by MF (partial deletion bacteria) along some viruses (but not a certain obstacle to viruses) and humic materials. Membrane fouling is a main obstacle which restricts wide using MBR. In addition, further membrane cleaning and associated costs are also of high concern for MBR users. Recognizing fouling mechanisms is substantial for controlling membrane fouling, including the characteristics of the constituents causing membrane fouling and fouling factors (Stephenson et al. 2000). The membrane fouling in MBR can be attributed to membrane pore constriction, pore blocking as well as cake layer formation by sludge particles, colloids and solutes. Generally, reversible fouling is because of cake layer formation, while irreversible fouling is due to pore blocking (Meng et al. 2009).

Metal ions have a considerable role in the formation of fouling layers, bridging the deposited cells, and biopolymers result in a dense cake layer (Costa et al. 2006). Bound extracellular polymeric substances (EPSs), soluble microbial products (SMPs) and biomass secretion exist in the MBR systems regarded as the main foulants. SMP and EPS can accumulate on the membranes or penetrate into membrane pores. EPS in both bound and soluble form is currently recognized as the predominant cause of membrane fouling in MBRs. Bound EPS involves proteins, polysaccharides, nucleic acids, lipids, humic acids, etc., located at or outside the cell surface. SMP can be described as the pool of organic compounds releasing into solution from substrate metabolism (usually with biomass growth) and biomass decay (Barker and Stuckey 1999).

The factors affecting membrane fouling can be categorized into four groups: membrane materials, biomass characteristics, feed characteristics and operating conditions. The intricate interactions between these aspects make more difficult the understanding of membrane fouling (Le-Clech et al. 2006). Aeration (Trussell et al. 2007), solid retention time (SRT) (Rosenberger et al. 2006), hydraulic retention time (HRT) (Laspidou and Rittmann 2002), food-to-microorganism ratio $(F / M)$ (Cicek et al. 2001, Trussell et al. 2006), temperature (Morgan-Sagastume and Allen 2005), coarse bubble (Fane et al. 2005), dissolved oxygen (DO) (Min et al. 2008) and other operational parameters all have various influences on membrane fouling (Dufresne et al. 1997). The modified membranes by $\mathrm{TiO}_{2}$ (Bae and Tak 2005), $-\mathrm{NH}_{2}$ (Yu et al. 2005a), $-\mathrm{COOH}$ (Yu et al. 2005b) and magnetic nanoparticle (Zinadini et al. 2014) can be more hydrophilic than unmodified membranes due to higher affinity of metal oxides and hydrophilic groups $\left(-\mathrm{NH}_{2},-\mathrm{COOH}\right)$ to water. The membrane permeability of aerobic granular sludge membrane bioreactor (AGMBR) was more than $50 \%$ higher than conventional MBR, while AGMBR had more severe irreversible fouling ( $\mathrm{Li}$ et al. 2005).

The overgrowth of filamentous bacteria resulted in the sharp increase in bound EPS concentration and then induced the increase in sludge viscosity and sludge hydrophobicity ( $\mathrm{Su}$ et al. 2008). Addition of an optimum calcium concentration as coagulants could induce lower SMP concentration led to cake layer resistance and decreasing pore blocking resistance (Kim and Jang 2006). In fact, mixed liquor suspended solids (MLSS) or biomass concentration has a complex interaction with MBR fouling. Substrate type or feed water composition affects the formation and elimination of SMP. McAdam et al. (2007) observed that carbon substrate had a great influence on floc stability (McAdam et al. 2007). The lower EPS concentrations at the higher protein-to-carbohydrate ratios (4/1 and 8/1) caused smaller flocs leading to higher cake resistance and higher fouling rates (Arabi and Nakhla 2008).

In this study, the performance of an activated sludge followed by membrane process (AS-MP) with MF and UF membranes treating three different wastewaters (with biological oxygen demand to chemical oxygen demand $\left(\mathrm{BOD}_{5} / \mathrm{COD}\right)$ ratios of $0.36,0.65$ and 0.83 ) at different operating conditions (HRT and operating pressure) was investigated. In this regard, the AS-MP system was operated at different HRTs 4-20 h with biomass concentration of $7000-8000 \mathrm{mg} / \mathrm{l}$ and constant chemical oxygen demand (COD) $1000 \mathrm{mg} \mathrm{L}^{-1}$. The performance of a commercial polyvinylidene fluoride (PVDF) MF membrane and a synthetic $\mathrm{ZnFe}_{2} \mathrm{O}_{4} / \mathrm{SiO}_{2}$ embedded polyether sulfone (PES) UF membrane under optimal operating pressure was compared, and the best membrane was recognized to treat three different wastewaters. Total chemical oxygen demand (TCOD) removal efficiency, sludge volume index (SVI), turbidity, feed flux $\left(J_{\text {feed }}\right)$ and flux recovery ratio (FRR) were measured and calculated as process responses. $\mathrm{ZnFe}_{2} \mathrm{O}_{4} /$ $\mathrm{SiO}_{2}$ is a magnetic, non-toxic and low-cost nanoparticle which induced higher hydrophilicity to the membrane surface. This affected the pure water flux, hydrophilicity and antifouling properties of the fabricated membranes. Usually, the magnetic polymer composites can be tailored to exhibit some new properties such as good film forming and processing properties, besides electrical, magnetic and optical properties (Zinadini et al. 2014). 


\section{Materials and methods}

\section{Wastewater characteristics}

The characteristics of three different wastewaters used in this study including soft drink, pineapple fruit juice and amoxicillin wastewaters are shown in Table 1. These wastewaters were stored in cool room to avoid any changes in their characteristics. Supplementary nutrients such as nitrogen $\left(\mathrm{NH}_{4} \mathrm{Cl}\right)$ and phosphorous $\left(\mathrm{KH}_{2} \mathrm{PO}_{4}\right)$ were added to wastewaters to give a ratio of COD/N/P of 100:5:1.

Table 1 Wastewaters characteristics

\begin{tabular}{lllc}
\hline Wastewaters & Parameter & Unit & Amount \\
\hline Soft drink & TCOD & $\mathrm{mg} / \mathrm{L}$ & $970-1050$ \\
& BOD $_{5}$ & $\mathrm{mg} / \mathrm{L}$ & $805-871$ \\
& $\mathrm{pH}$ & - & $7-7.5$ \\
& $\mathrm{TN}$ & $\mathrm{mg} / \mathrm{L}$ & $54.3-66.6$ \\
& $\mathrm{TP}$ & $\mathrm{mg} / \mathrm{L}$ & $13.7-15.9$ \\
Pineapple fruit juice & $\mathrm{TCOD}$ & $\mathrm{mg} / \mathrm{L}$ & $970-1050$ \\
& $\mathrm{BOD}_{5}$ & $\mathrm{mg} / \mathrm{L}$ & $611-661$ \\
& $\mathrm{pH}$ & - & $7.6-8$ \\
& $\mathrm{TN}$ & $\mathrm{mg} / \mathrm{L}$ & $71-84$ \\
& $\mathrm{TP}$ & $\mathrm{mg} / \mathrm{L}$ & $16.1-20.3$ \\
Amoxicillin & $\mathrm{TCOD}$ & $\mathrm{mg} / \mathrm{L}$ & $970-1050$ \\
& $\mathrm{BOD}$ & $\mathrm{mg} / \mathrm{L}$ & $349-378$ \\
& $\mathrm{pH}$ & - & $7.5-7.8$ \\
& $\mathrm{TN}$ & $\mathrm{mg} / \mathrm{L}$ & $49-55.5$ \\
& $\mathrm{TP}$ & $\mathrm{mg} / \mathrm{L}$ & $11-13.8$ \\
\hline
\end{tabular}

\section{Seed sludge preparation}

The seeding source of the reactor was the sludge taken from aerobic sludge digester of Faraman industrial estate, Kermanshah, Iran. Mixed liquor suspended solids concentration of the seed was initially measured as $7000-8000 \mathrm{mg} / \mathrm{l}$.

\section{Membrane separation section}

In this work, in order to evaluate the effect of feed composition on membrane fouling, a commercial MF membrane (with a thickness of $125 \mu \mathrm{m}$ and nominal pore size of $0.22 \mu \mathrm{m}$ obtained from Millipore Corporation) and highperformance synthetic $\mathrm{ZnFe}_{2} \mathrm{O}_{4} / \mathrm{SiO}_{2}$ nanoparticles embedded polyether sulfone (PES) ultrafiltration (UF) membrane were applied. The UF membrane was prepared via wet phase inversion method using casting solutions involving PES (15 wt \%), PVP (1 wt \%) and $0.5 \mathrm{wt} \% \mathrm{ZnFe}_{2} \mathrm{O}_{4} / \mathrm{SiO}_{2}$ magnetic nanoparticles in dimethylacetamide (DMAc) as solvent. The coagulation bath during phase inversion was exposed to magnetic field ( 0.1 Tesla) in order to migration of hydrophilic nanoparticles on the membrane surface and inducing antifouling capability. A complete description of the procedure has been presented elsewhere (Zinadini et al. 2014).

\section{AS-MP setup}

The AS-MP used in this study, as shown in Fig. 1, consisted of a plexiglass aeration tank with a working volume of $3 \mathrm{~L}$ (the total volume of aeration tank was $4 \mathrm{~L}$ with $13 \mathrm{~cm}$ inner diameter and $30 \mathrm{~cm}$ height) and a sedimentation tank (the total volume of sedimentation tank was $3.5 \mathrm{~L}$ with $10 \mathrm{~cm}$ inner diameter and $50 \mathrm{~cm}$ height). Synthetic wastewater kept in a polyethylene tank was fed to the reactor by a peristaltic
Fig. 1 Schematic structure of AS-MP used in this study

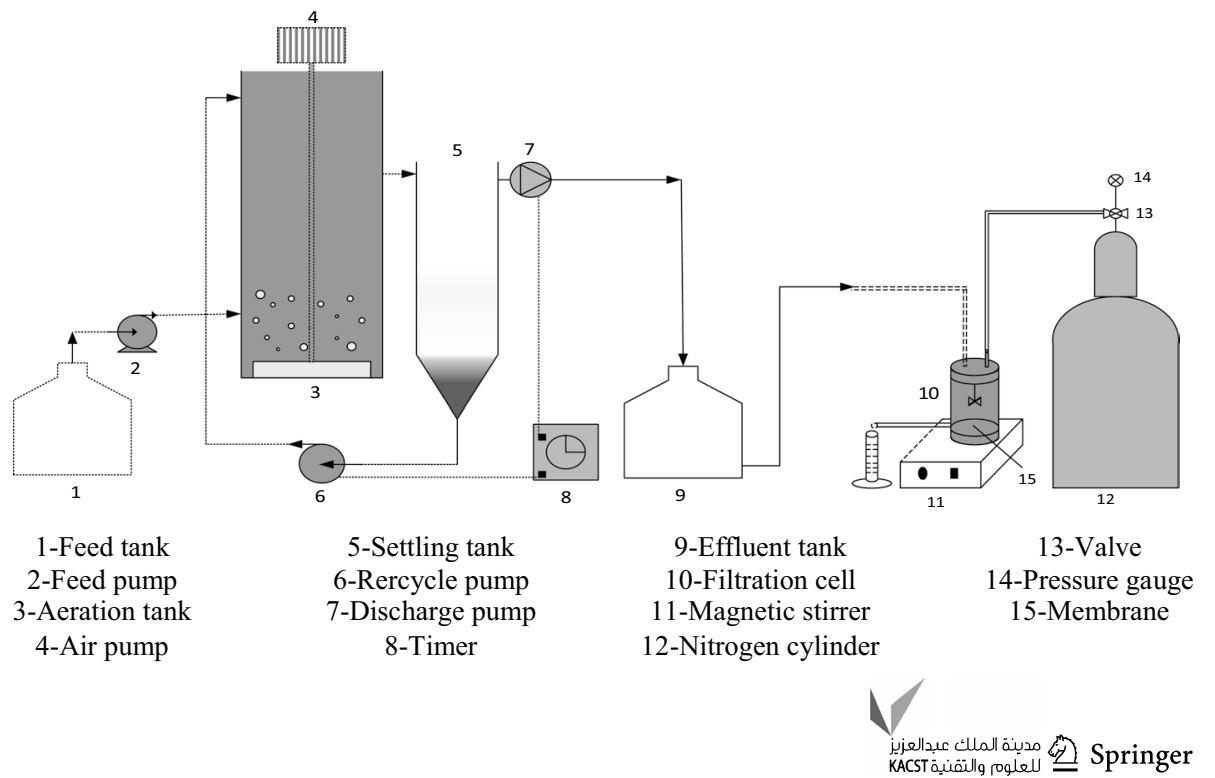


pump (PD5201, Heidolph, Germany) at desired flow rates. The reactor was aerated using an air pump and several porous diffusers. The dissolved oxygen (DO) concentration in the bioreactor was $2.5-4 \mathrm{mg} / \mathrm{L}$. A sedimentation tank was placed after the aeration tank to provide the required biomass concentration in the system by recycling activated sludge using a centrifuge pump. The treated wastewater at the top of the settling tank was discharged from the tank as final effluent. The reason of the use of settling tank was to study the effects of soluble matters from different wastewaters on the membrane performance. The bioreactor was tested at different levels of HRTs. After reaching steady-state conditions, a sample of effluent was taken from the sedimentation tank to do the filtration process using the commercial microfiltration (MF) and synthesized ultrafiltration (UF) membranes. The synthesized ultrafiltration (UF) and commercial microfiltration (MF) membranes were put on rigid sponge and placed in the dead-end stirred cell. The cell was fitted with a pressure gauge. Pressurized nitrogen gas was used to force the liquid through the membrane.

\section{System operation procedure}

The experimental conditions examined in this study are presented in Table 2. As can be seen in Table 2, three different wastewaters with different $\mathrm{BOD}_{5} / \mathrm{COD}$ ratios $(0.36$, 0.65 and 0.83 ) were selected. The AS-MP system was operated in completely stirred hydraulic regime (3-lit activated sludge (AS) system) with biomass concentration (MLSS) 7000-8000 $\mathrm{mg} / \mathrm{l}$ and different hydraulic retention times (HRTs) 4-20 h to treat three various wastewaters with constant COD $1000 \mathrm{mg} / \mathrm{l}$. In the first stage, TCOD removal, sludge volume index (SVI) and turbidity at different HRTs for three wastewaters (with different $\mathrm{BOD}_{5} / \mathrm{COD}$ ratios) were measured and calculated as process responses.

In the second stage, membrane performance in terms of feed flux $\left(J_{\text {feed }}\right)$ and flux recovery ratio (FRR) at different HRTs for three wastewaters was investigated. The operational pressure of MF and UF processes was adjusted at 10 and 30 psi, respectively. It must be noted that the main objective is to introduce a membrane bioreactor to achieve higher performance in terms of effluent characteristics and membrane fouling. In this mean, the performance of a modified UF with improved hydrophilicity and antifouling properties was compared with commercial MF membrane. It should be noted that the samples used for membrane separation were taken from clear zone of settling tank.

In the third stage, in order to investigate the effect of operating pressure on membrane fouling, the performance of membranes was examined at different operating pressures at optimal HRTs. Feed flux $\left(J_{\text {feed }}\right)$ and flux recovery ratio (FRR) were measured and calculated as responses to assess the function of the membranes at different conditions.

In the fourth stage, to investigate the effect of cake formation on membrane fouling during treatment of wastewater, first, the pure water flux of membranes was calculated at optimal pressures determined in the earlier stage for $\mathrm{MF}$ and UF membranes as $J_{\mathrm{w} .1}$. Then, at optimal run of each wastewater, flux $\left(J_{\text {Feed }}\right)$ was calculated at adjusted pressure over long-term filtration (500 min). Due to high wash out of microorganisms in the bioreactor, this time was sufficient for thin layer cake formation on membrane surface. Finally, the pure water flux was calculated again after placing the membrane in distilled water for $20 \mathrm{~min}$ as $J_{\mathrm{w} .2}$. In a steady-state situation, the values of flux feed $\left(J_{\text {Feed }}\right)$, flux recovery ratio (FRR) and flux reduction percent (FR\%) were calculated.
Table 2 Experimental conditions

\begin{tabular}{lccc}
\hline Type of wastewater & \multicolumn{3}{l}{ Operating conditions } \\
\cline { 2 - 4 } & HRT $(\mathrm{h})$ & MLSS $(\mathrm{mg} / \mathrm{l})$ & $\mathrm{COD}_{\text {in }}(\mathrm{mg} / \mathrm{l})$ \\
\hline Soft drink wastewater $\left(\mathrm{BOD}_{5} / \mathrm{COD}=0.83\right)$ & 4 & $(7000-8000)$ & 1000 \\
& 8 & & \\
Pineapple fruit juice wastewater $\left(\mathrm{BOD}_{5} / \mathrm{COD}=0.63\right)$ & 12 & & \\
& 20 & & \\
& 4 & & \\
& 8 & & \\
& 12 & & \\
Amoxicillin wastewater $\left(\mathrm{BOD}_{5} / \mathrm{COD}=0.36\right)$ & 16 & & \\
& 20 & & \\
& 4 & & \\
& 8 & & \\
\end{tabular}


In the last stage, in order to investigate the effect of wastewater type on membrane fouling during long-term filtration, 10 times of the filtration test were performed. The effluent of bioreactor at optimal run of each wastewater was passed through membranes over $60 \mathrm{~min}$ after this time, and a very thin cake layer was formed on membrane surface that affected on membrane permeability. In order to removal of this effects and considering of only irreversible fouling, the fouled membrane was dipped into distilled water for omitting reversible fouling about $5 \mathrm{~min}$. The cleaned membrane was placed in dead-end cell again and refilled with effluent of bioreactor for more filtration. This procedure was repeated 10 times for both MF and UF membrane at optimal pressures for each wastewater. In a steady-state situation, the values of $J_{\text {feed }}$ were measured.

\section{Parameters studied}

In this study, in order to evaluate the performance of the system, different parameters as process response were measured and calculated. The parameters are: TCOD removal, SVI, $J_{\text {feed }}$, FRR and FR.

$\operatorname{COD} \operatorname{removal}(\%)=\left(\frac{\mathrm{COD}_{\text {in }}-\mathrm{COD}_{\text {out }}}{\mathrm{COD}_{\text {in }}}\right) \times 100$

SVI $=\left(\frac{\text { settled sludge volume }\left(\frac{\mathrm{ml}}{1}\right)}{\text { suspended solids }\left(\frac{\mathrm{mg}}{1}\right)}\right) \times 1000$

$J_{w, 1}=\frac{M}{A \Delta t}$

$\operatorname{FRR}(\%)=\left(\frac{J_{w, 2}}{J_{w, 1}}\right) \times 100$

$\operatorname{FR}(\%)=\left(\frac{\text { The final flux }}{\text { The initial flux }}\right) \times 100$

where $M(\mathrm{~kg})$ is the weight of permeated water, $A\left(\mathrm{~m}^{2}\right)$ is the membrane area, and $\Delta t(\mathrm{~h})$ is the permeation time. Permeates were collected over a given period and weighed.

\section{Analytical procedure}

The concentrations of chemical oxygen demand (COD), biological oxygen demand (BOD), total Kjeldahl nitrogen $(\mathrm{TKN})$, nitrate $\left(\mathrm{NO}_{3}^{-}\right)$, phosphate $\left(\mathrm{PO}_{4}^{3-}\right)$, sludge volume index (SVI), turbidity (Turb.) and MLSS of the system were determined by using standard methods for the examination of water and wastewater (APHA 1999). For COD, a colorimetric method with closed reflux procedure was developed. Spectrophotometer (6320D, Jenway, USA) at $600 \mathrm{~nm}$ was used to measure the absorbance of COD samples. The DO concentration in wastewater was determined using a DO probe. DO meter was supplied by WTW DO Cell OX 330, electro DO probe, Germany. Turbidity was measured by a turbidity meter model $2100 \mathrm{P}$ (Hach Co., USA).

\section{Results and discussion}

\section{Bioreactor performance}

\section{COD removal}

Table 3 presents the operating condition and the obtained results from bioreactor treating different wastewaters. To design a biological wastewater treatment system, it is most desirable to achieve higher COD removal at lower HRT. Therefore, an optimum (minimum) HRT is needed to be experimentally found. The COD removal efficiency for different wastewaters is shown in Table 3. The steadystate data were collected after several turnovers. Soft drink wastewater with $\mathrm{BOD}_{5} / \mathrm{COD}$ ratio of 0.83 was used as first substrate in the AS-MP. As can be seen in Table 3, slightly the COD removal efficiency decreased from 95.4 to $87.1 \%$ with an increase in HRT from 4 to $20 \mathrm{~h}$. The relatively high $\mathrm{BOD}_{5} / \mathrm{COD}$ ratio of the soft drink wastewater indicates high biodegradability. As reported in Table 3, the highest COD removal efficiency has been achieved at the lowest HRT. It seems that during the starvation phase, soluble microbial products (SMP) are released from the microbial aggregates to the bulk phase and the released quantity increases with the starvation length. The starvation phenomenon is intensified by decreasing food-tomicroorganism ratio $(F / M)$ from 0.77 to $0.152 \mathrm{~d}^{-1}$ that is depicted in Table 3. This can accumulate SMPs which are little or very slowly biodegradable (Charmot-Charbonnel et al. 1999). In a similar research work, a decreasing trend in TCOD removal efficiency was observed with an increase in HRT from 12 to $36 \mathrm{~h}$ (corresponding to $F / M$ of $0.4-0.11 \mathrm{~d}^{-1}$ ) (Asadi et al. 2012a).

Pineapple fruit juice production wastewater with $\mathrm{BOD}_{5} /$ COD ratio of 0.63 was used as second feed in AS-MP, and the treatment process data are presented in Table 3. From the results, by increasing HRT from 4 to $20 \mathrm{~h}$, the response was increased from 65.7 to $81.3 \%$. It is noted that HRTs higher than $8 \mathrm{~h}$ did not show significant effect.

From the literature, for the treatment of concentrated fruit juice wastewater with $\mathrm{BOD}_{5} / \mathrm{COD}$ ratio of 0.66 , the maximum COD removal efficiency (98\%) was obtained in a condition with an initial biomass concentration

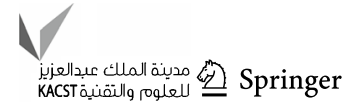


Table 3 The operating conditions and the results obtained for treating different wastewaters

\begin{tabular}{|c|c|c|c|c|c|c|c|}
\hline Type of wastewater & HRT, h & MLSS, mg/l & $F / M, \mathrm{~d}^{-1}$ & $\mathrm{DO}, \mathrm{mg} / \mathrm{l}$ & $\mathrm{SVI}, \mathrm{ml} / \mathrm{g}$ & $\begin{array}{l}\text { Effluent turbid- } \\
\text { ity, NTU }\end{array}$ & COD removal, $\%$ \\
\hline \multirow[t]{5}{*}{ Soft drink } & 4 & 7800 & 0.77 & 3.7 & 31.5 & 38.6 & 95.4 \\
\hline & 8 & 7300 & 0.43 & 3.9 & 57.7 & 73.1 & 92.8 \\
\hline & 12 & 7400 & 0.273 & 4.2 & 90.6 & 77.1 & 89.1 \\
\hline & 16 & 7600 & 0.177 & 4.2 & 78.5 & 81.5 & 88.1 \\
\hline & 20 & 7300 & 0.152 & 3.9 & 60.2 & 170 & 87.1 \\
\hline \multirow[t]{5}{*}{ Pineapple fruit juice } & 4 & 7100 & 0.90 & 3.8 & 51.5 & 60 & 65.7 \\
\hline & 8 & 7900 & 0.453 & 3.5 & 68.1 & 70.2 & 79.0 \\
\hline & 12 & 7200 & 0.352 & 3.9 & 132.8 & 110 & 79.6 \\
\hline & 16 & 7000 & 0.233 & 3.4 & 140.6 & 114 & 83.8 \\
\hline & 20 & 7300 & 0.182 & 4.0 & 155 & 138 & 81.3 \\
\hline \multirow[t]{5}{*}{ Amoxicillin } & 4 & 7400 & 0.81 & 4.1 & 33.8 & 107 & 34.0 \\
\hline & 8 & 7600 & 0.387 & 4.2 & 40.8 & 124 & 85.5 \\
\hline & 12 & 7400 & 0.287 & 4.2 & 70.4 & 112 & 86.0 \\
\hline & 16 & 7400 & 0.205 & 4.0 & 57.9 & 116 & 94.5 \\
\hline & 20 & 7800 & 0.18 & 3.9 & 38.4 & 104 & 94.0 \\
\hline
\end{tabular}

between 2000 and $3000 \mathrm{mg} / \mathrm{l}$, initial COD loads of 20,000 $\mathrm{mgCOD} / \mathrm{l}$, aeration period of $18 \mathrm{~h}$ /day and retention time of 14 days (Amor et al. 2012).

Finally, amoxicillin wastewater with $\mathrm{BOD}_{5} / \mathrm{COD}$ ratio of 0.36 was used as third substrate in the AS-MP. The steady-state performance data of the AS-MP are summarized in Table 3. As can be seen in the table, an increasing trend in TCOD removal efficiency from 34 to $94 \%$ was observed with an increase in HRT from 4 to $20 \mathrm{~h}$ and a decreasing in $F / M$ ratio from 0.81 to $0.18 \mathrm{~d}^{-1}$. Higher biodegradability might be expected in the wastewater treatment process where high biomass concentration was employed. Higher HRTs usually result in better removal performance in a wastewater with low $\mathrm{BOD}_{5} / \mathrm{COD}$ ratio such as amoxicillin (Isma et al. 2014). A high COD removal can be expected due to full particle retention promoting the adsorption onto the sludge flocks (Radjenovic et al. 2008). Maximum TCOD removal efficiency was found to be $94.5 \%$ at HRT of $16 \mathrm{~h}$. The obtained results indicated that higher COD removal efficiency can be achieved at higher HRT due to the slight decrease in amoxicillin loading rates in the system. However, the high extent of amoxicillin loading rate was not significantly effective in biological amoxicillin removal efficiencies.

In another study, for the treatment of a pharmaceutical wastewater contaminated with amoxicillin, the optimum COD and total suspended solids (TSSs) removal efficiencies of $83.2 \%$ and $78.8 \%$ were achieved after 24 h retention time, respectively (SI and MA).

By comparing the results from different wastewaters at low HRTs (4 and $8 \mathrm{~h}$ ) in Table 3 , it is shown that as BOD 5 / COD ratio increases, the effect of HRT becomes less. As a result, it is recommended that the system to be operated at lower $F / M$ for lower $\mathrm{BOD}_{5} / \mathrm{COD}$ ratios.

\section{Effluent turbidity}

The effluent turbidity of wastewater treatment plants depends on the quantity of solid matters present in the suspension state. Table 3 illustrates effluent turbidity under different HRTs for three wastewaters studied. For soft drink wastewater, by increasing HRT from 4 to $20 \mathrm{~h}$, the effluent turbidity increased from 38.6 to 170 NTU. This could be due to the microbial floc disintegration at higher HRTs. Higher values of turbidity in AS-MP system could be because of cell debris during biological treatment. It is known that flocculated sludge shows more sweeping impact (Asadi et al. 2012b). These results are confirmed by SVI measurements that are discussed in next section.

For pineapple fruit juice wastewater, the effluent turbidity was increased from 60 to 138 NTU after setting in the bioreactor by increasing HRT from 4 to $20 \mathrm{~h}$. This behavior can be attributed to the dispersion of filaments from the flocs into the bulk solution that induced by filamentous bacteria which lead to a decrease in density of the floc and therefore adverse settling and higher turbidity (Ozbas et al. 2006). According to the measured effluent turbidity for amoxicillin wastewater shown in Table 3, the variation of data was between 104 and 124 NTU. Slight changes in the effluent turbidity were observed with increasing in HRT.

From the results of Table 3, for the wastewater with high $\mathrm{BOD}_{5} / \mathrm{COD}$ ratio, the biochemical reaction rate is high. This causes an increase in the effluent turbidity as HRT increases due to relative disintegration of the microbial floc. 


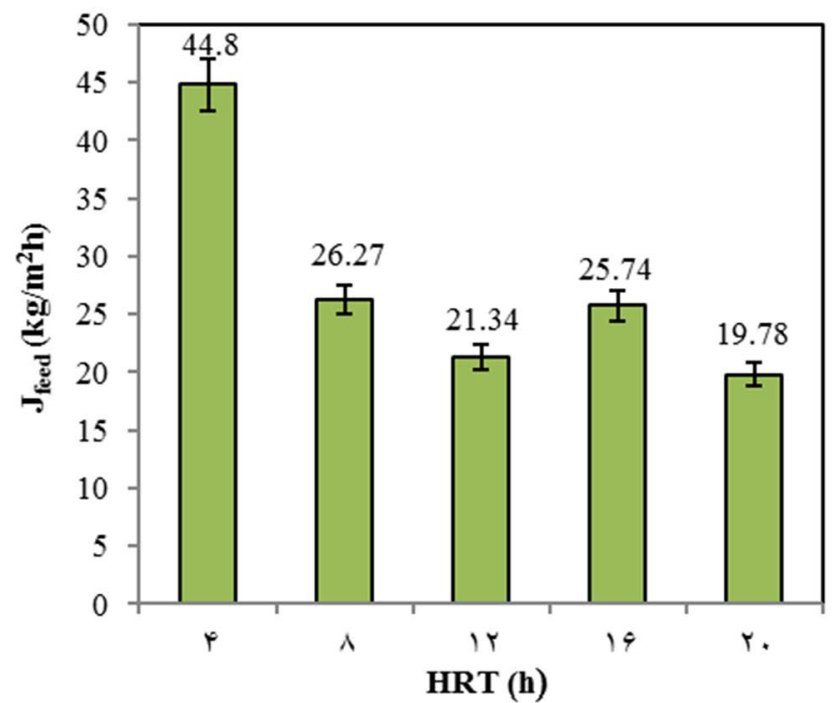

(a)

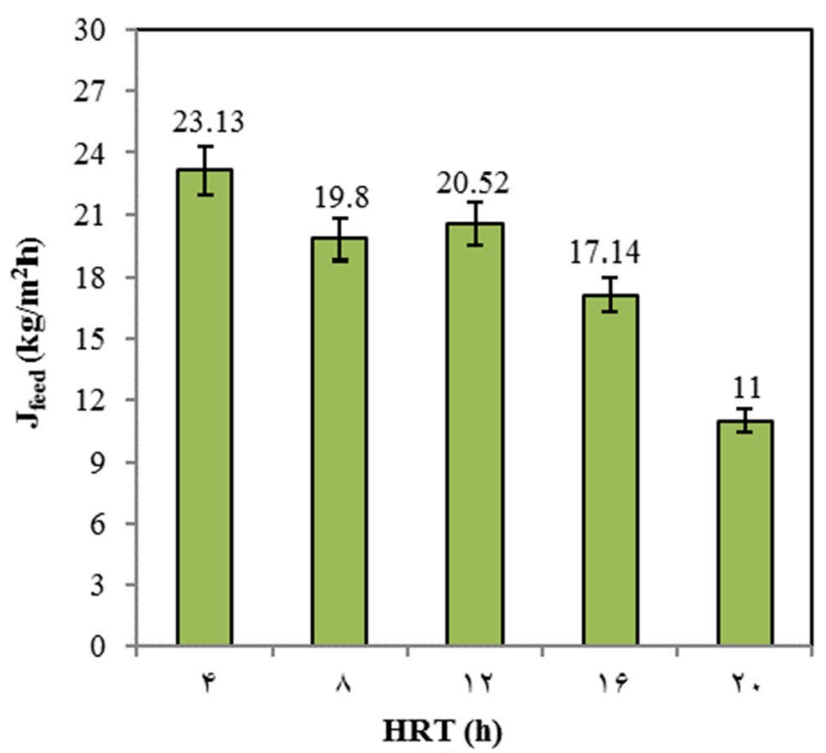

(c)

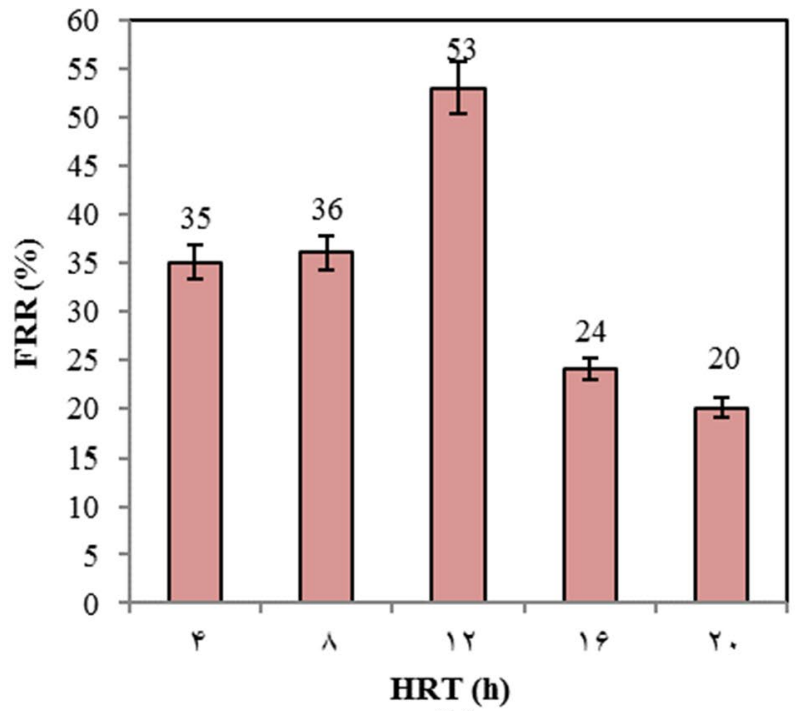

(b)

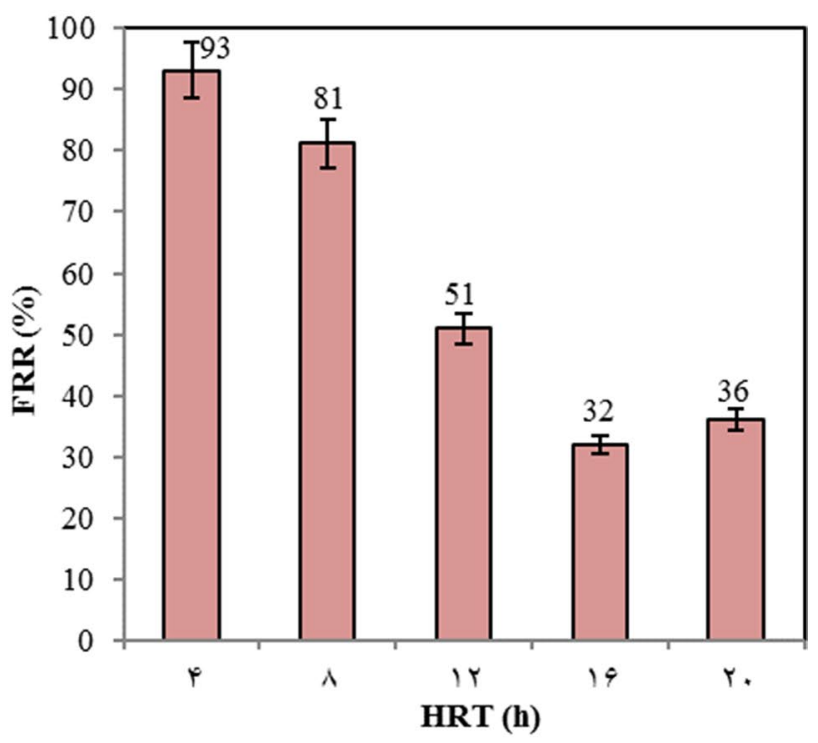

(d)

Fig. $2 J_{\text {feed }}\left(\right.$ a) and FRR (b) measured for MF membrane at constant pressure of 10 psi and $J_{\text {feed }}(\mathbf{c})$ and FRR (d) measured for UF membrane at constant pressure of $30 \mathrm{psi}$ at different HRTs for soft drink wastewater

\section{Sludge volume index (SVI)}

In this study, effluent SVI was measured as a response and its variation as a function of $F / M$ ratio at different operating conditions. The SVI data for the three types of wastewater are shown in Table 3. Table 3 shows SVI for soft drink wastewater that indicates a reverse impact of HRT on SVI, increasing effect from 31.5 to $90.6 \mathrm{ml} / \mathrm{g}$ with an increase in HRT from 4 to $12 \mathrm{~h}$ and decreasing effect from 90.6 to $60.2 \mathrm{ml} / \mathrm{g}$ by further increase in HRT from 12 to $20 \mathrm{~h}$. It should be mentioned that the range of SVI obtained is in the normal range for AS systems. The increase in the response could be owing to a relatively high sludge concentration, $F / M$ ratio at HRT of $12 \mathrm{~h}$ was much lower than that at the initial stage and it could favor the fast growth of filamentous microorganisms. It must be noted that the size of flocs formed became smaller by increasing HRT (decreasing $F / M$ ) throughout the experiments which was associated with an increase in turbidity from the less sweeping impact. However, a decrease in SVI after an increase in HRT from 12 to $20 \mathrm{~h}$ was because of the smaller flocs which generates a relative denser sludge (SVI of $60 \mathrm{vs.} 90 \mathrm{ml} / \mathrm{g}$ ).

In the pineapple fruit juice wastewater (Table 3), SVI increased from the initial value of about $50 \mathrm{ml} / \mathrm{g}$ to a 


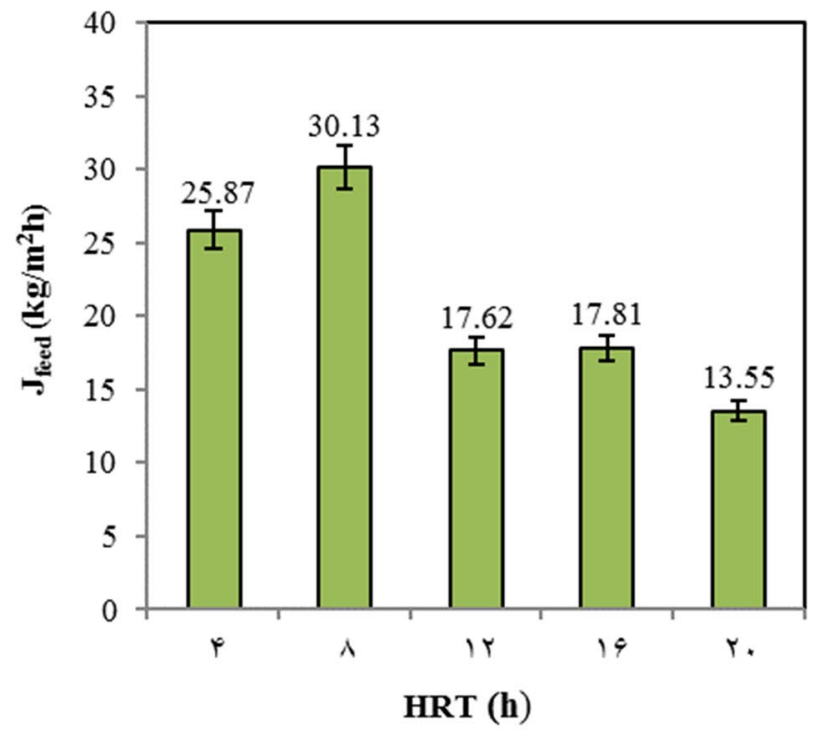

(a)

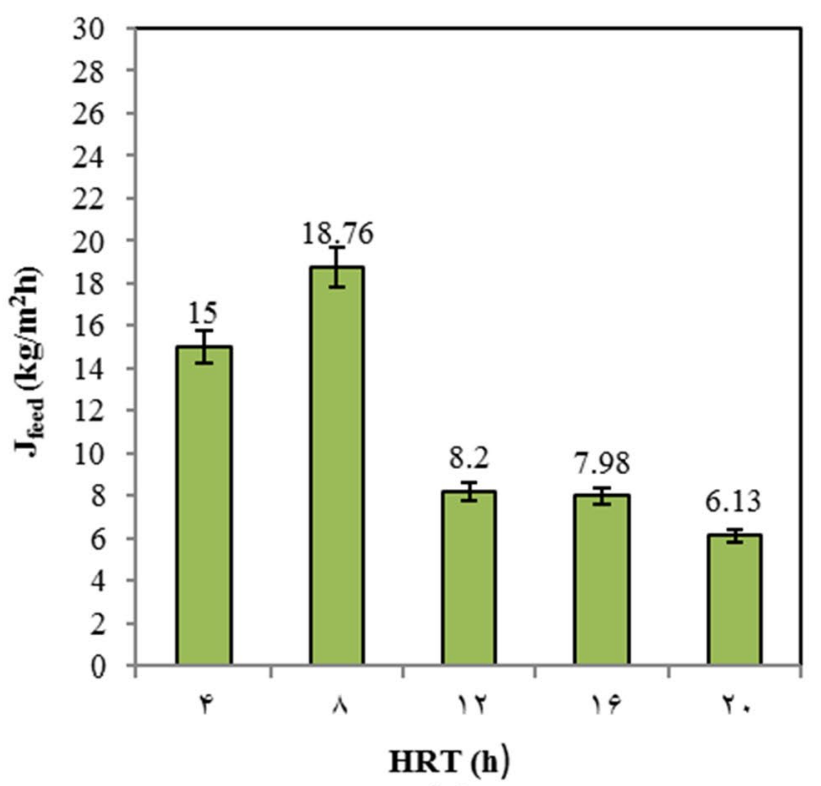

(c)

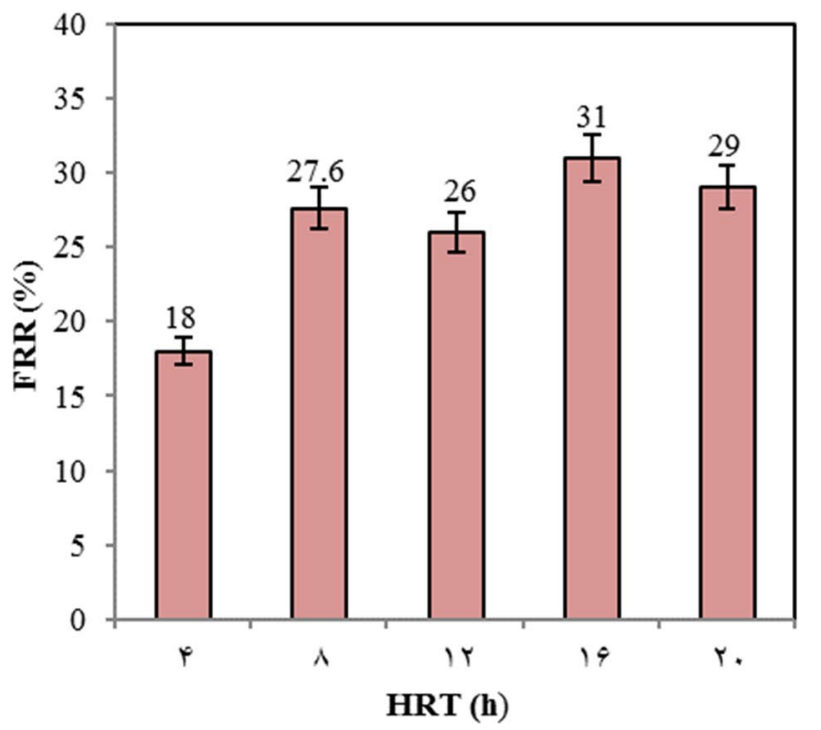

(b)

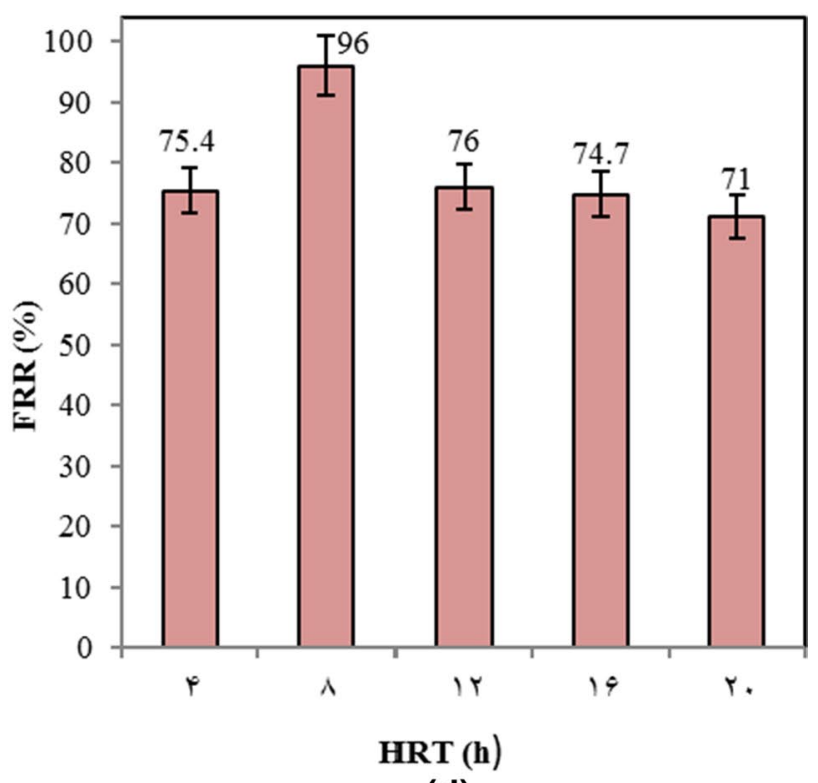

(d)

Fig. $3 J_{\text {feed }}\left(\right.$ a) and FRR (b) measured for MF membrane at constant pressure of 10 psi and $J_{\text {feed }}(\mathbf{c})$ and FRR (d) measured for UF membrane at constant pressure of $30 \mathrm{psi}$ at different HRTs for pineapple fruit juice wastewater

maximum value of $150 \mathrm{ml} / \mathrm{g}$ with an increasing in HRT from 4 to $20 \mathrm{~h}$, which may be related to the filamentous bacteria community in the bioreactor. The lowest SVI was obtained at the lowest HRT (4 h), and the highest SVI was obtained at the highest HRT $(20 \mathrm{~h})$. As reported in Table 3, SVI values were in the range of $34-70 \mathrm{ml} / \mathrm{g}$ for amoxicillin wastewater, indicating the presence of good settling sludge. On the other hand, as mentioned earlier in "Effluent turbidity" section, the effluent turbidity was higher than 100 NTU at all operating conditions for amoxicillin wastewater which might be related to low range of SVI derived from small and dense flocs.

\section{Performance of membrane filtration}

\section{Effect of HRT on membrane performance}

It is obvious that activated sludge characteristic is an important factor on membrane fouling in MBR system. Type of wastewater and operating condition affect the sludge characteristics which in turn have a significant impact on 


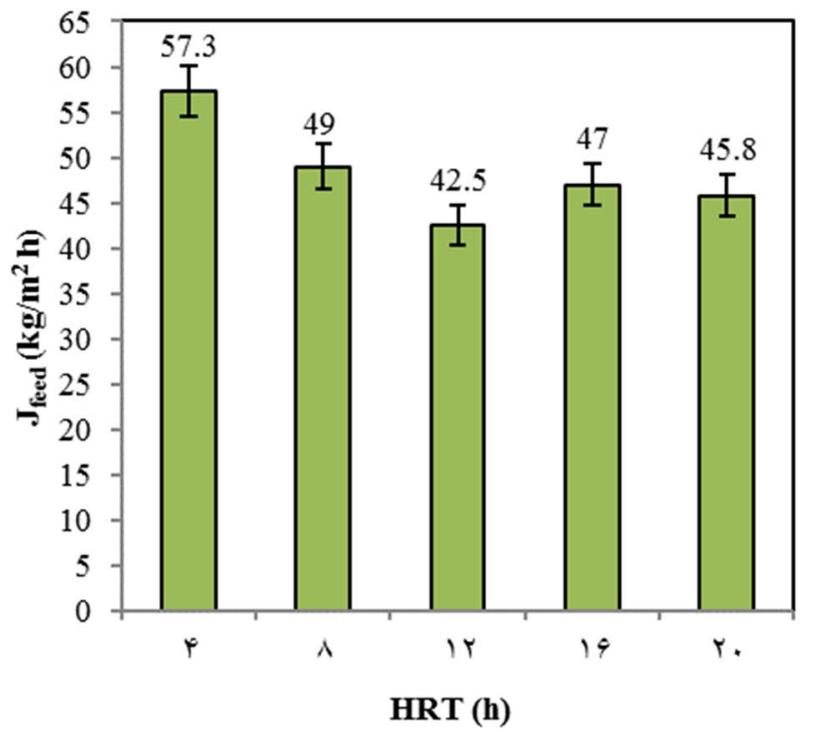

(a)

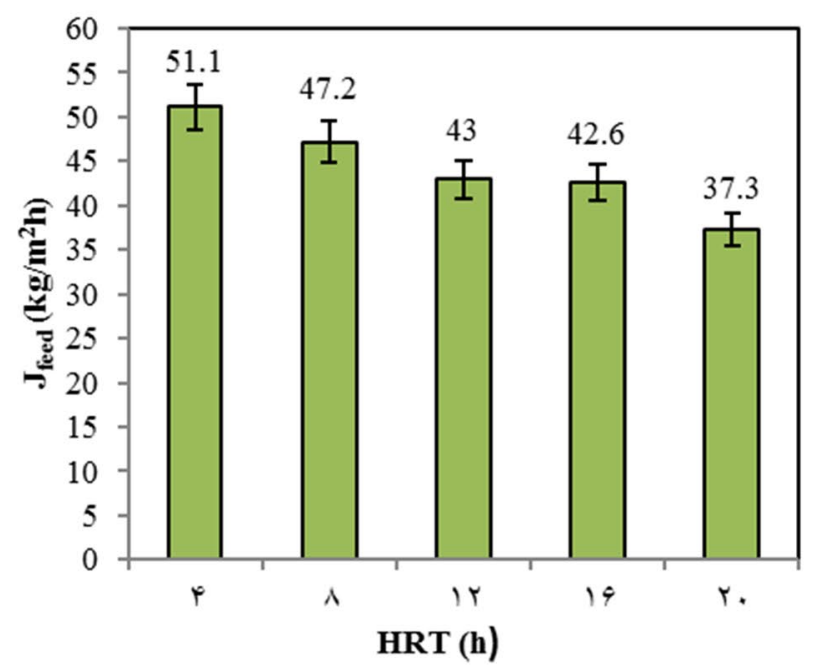

(c)

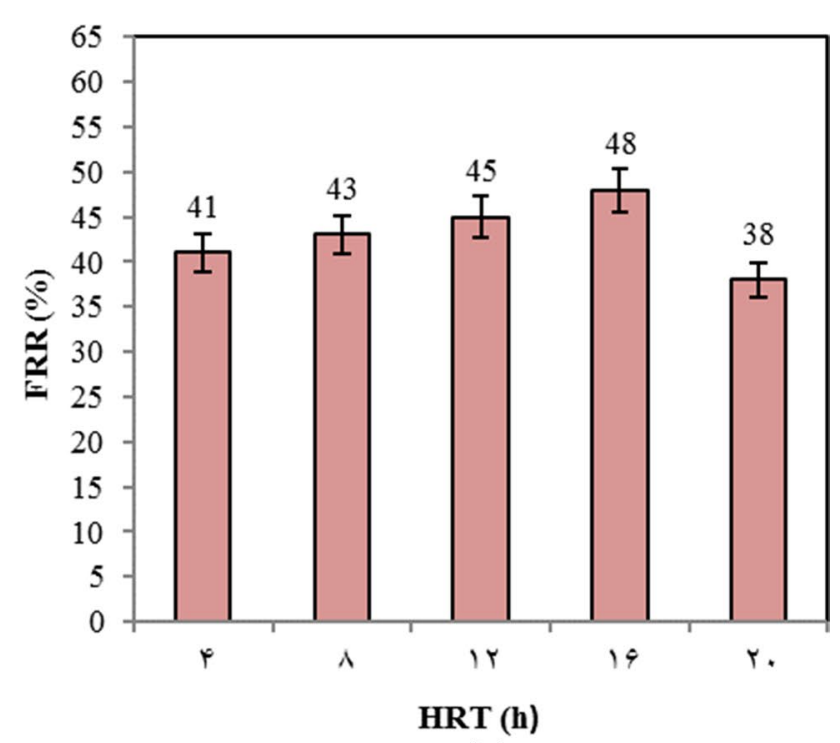

(b)

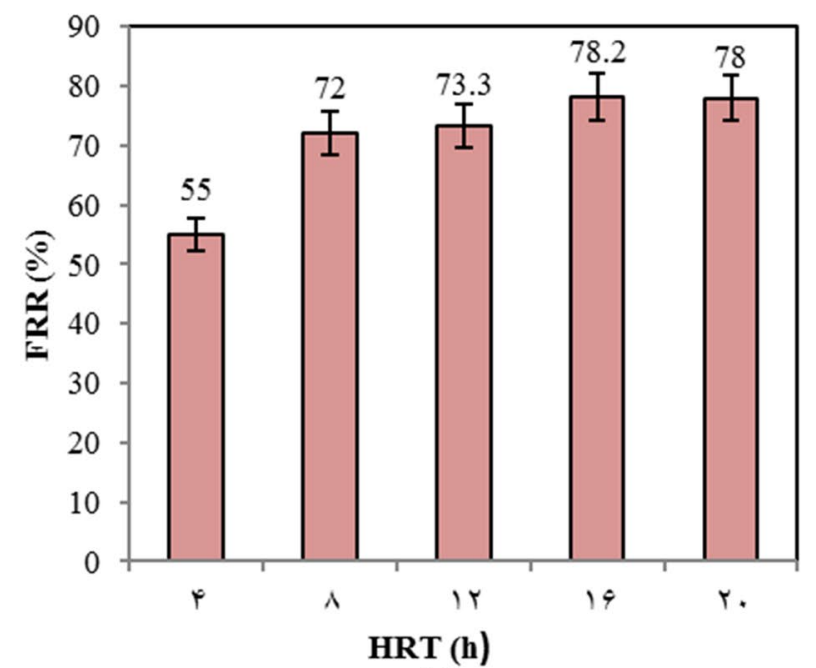

(d)

Fig. $4 J_{\text {feed }}(\mathbf{a})$ and FRR (b) measured for MF membrane at constant pressure of 10 psi and $J_{\text {feed }}(\mathbf{c})$ and FRR (d) measured for UF membrane at constant pressure of $30 \mathrm{psi}$ at different HRTs for amoxicillin wastewater

membrane performance. The operational pressure of MF and UF processes was adjusted at 10 and 30 psi, respectively. The results are depicted in Figs. 2, 3 and 4.

FRR, $J_{\text {Feed }}$, COD removal efficiency and effluent turbidity were considered as criteria to select the optimal condition for treatment of each wastewater. The runs with high FRR, $J_{\text {Feed }}$ and COD removal efficiency and low effluent turbidity were chosen as optimal run.

- Soft drink wastewater

From Table 3, it is obvious that with increasing HRT from 4 to $20 \mathrm{~h}$, the effluent turbidity was increased from 38.6 to
170 NTU. At this condition, $J_{\text {Feed }}$ was decreased from 44.8 to $19.78 \mathrm{~kg} / \mathrm{m}^{2} \mathrm{~h}$ in MF membrane and from 23.13 to $11 \mathrm{~kg} /$ $\mathrm{m}^{2} \mathrm{~h}$ in UF membrane (Fig. 2a, c). As a result, at HRT of $4 \mathrm{~h}$, the lowest effluent turbidity and the highest $J_{\text {Feed }}$ were obtained at both MF and UF membranes. In this research, it is assumed that the effluent turbidity affects the specific resistance of the cake. The results presented in Fig. $2 b, d$ indicated that the lowest FRRs were obtained at HRTs of 16 and $20 \mathrm{~h}$ for both MF and UF membranes. This result might be due to famine condition which stimulates the release of SMP (Asadi et al. 2012a). In contrast, the highest FRR was obtained at HRTs of 4 and $12 \mathrm{~h}$ for MF and $4 \mathrm{~h}$ for UF membrane. Higher SMP concentrations in the form 


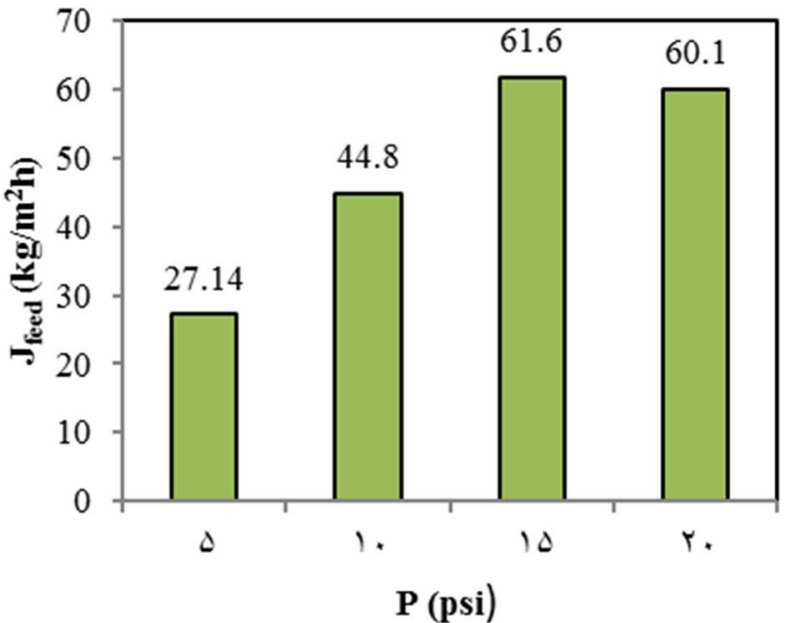

(a)

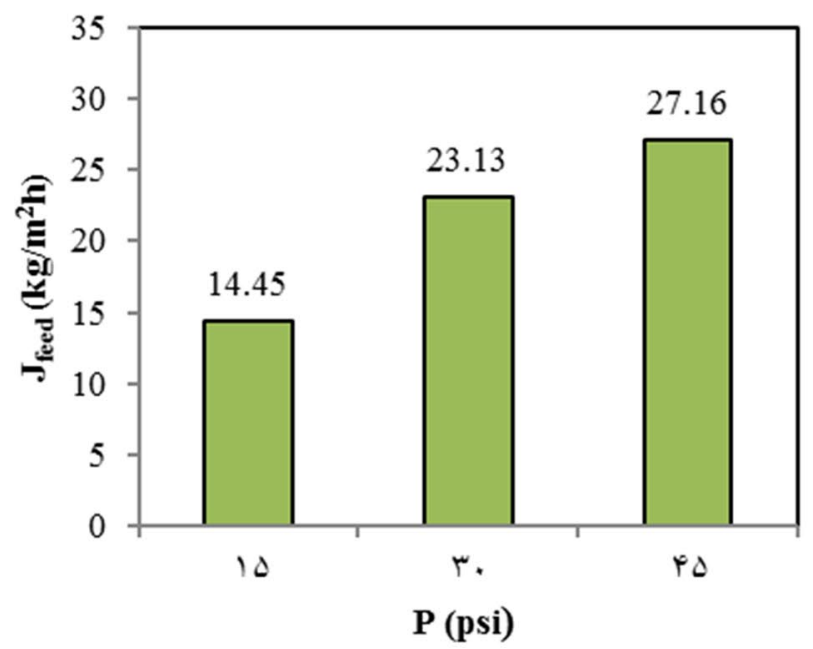

(c)

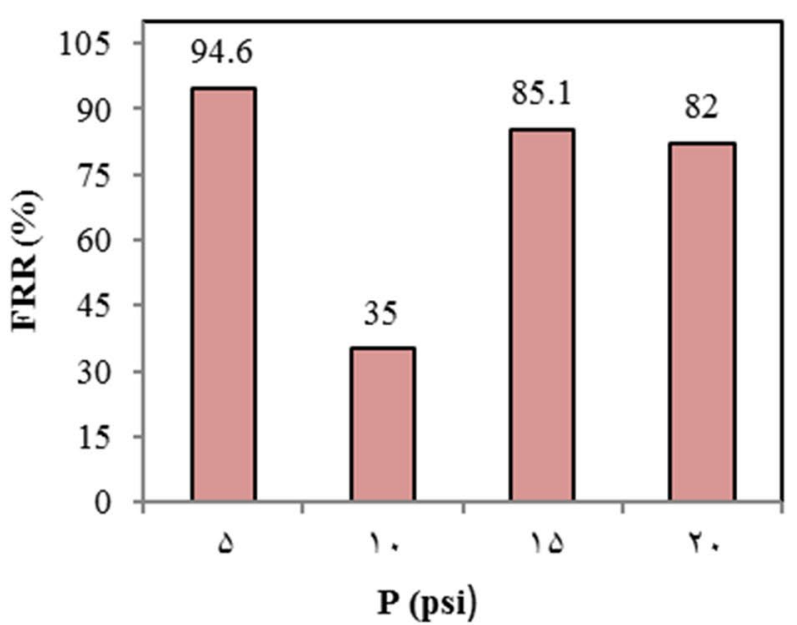

(b)

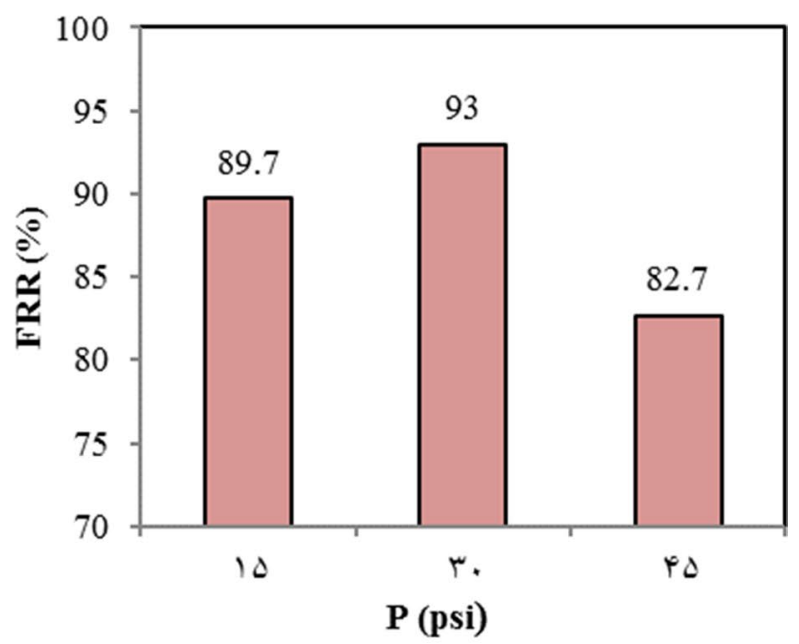

(d)

Fig. $5 J_{\text {Feed }}(\mathbf{a})$ and FRR (b) measured for MF membrane and $J_{\text {feed }}(\mathbf{c})$ and FRR (d) measured for UF membrane at different pressures for soft drink wastewater $(\mathrm{HRT}=4 \mathrm{~h})$

of carbohydrate and protein resulted in higher membrane fouling rates. Higher SMP concentrations cause higher pore blocking, and SMP aggregations serve as attachment sites for the bulk SMP. Furthermore, SMP could reduce the cake porosity seriously by filling the void spaces between the cell particles in the cake layer (Trussell et al. 2006).

Therefore, from Table 3 and Fig. 2, HRTs of 4 and $12 \mathrm{~h}$ were considered as optimal runs for the MF membrane and HRT of $4 \mathrm{~h}$ was selected as optimal run for the UF membrane. It should be mentioned that $J_{\text {feed }}$ value was not suitable enough at HRT of $12 \mathrm{~h}$ in the MF membrane. However, FRR was higher compared to other runs at HRT of $12 \mathrm{~h}$.

- Pineapple fruit juice wastewater
As shown in Table 3, the effluent turbidity was increased from 60 to $138 \mathrm{NTU}$ and SVI was increased from 51.5 to $155 \mathrm{ml} / \mathrm{g}$ with increasing HRT from 4 to $20 \mathrm{~h}$. The reason for these observations might be the growth of filamentous bacteria with increasing HRT from 4 to $20 \mathrm{~h}$. The extracellular polymeric substances (EPS) concentration usually increases as filamentous bacteria grow. This factor had negative effect on membrane fouling (Meng et al. 2007). Figure 3a, c shows that with increasing HRT from 8 to $20 \mathrm{~h}, J_{\text {Feed }}$ was decreased from 30.13 to $13.55 \mathrm{~kg} / \mathrm{m}^{2} \mathrm{~h}$ and from 18.76 to $6.13 \mathrm{~kg} / \mathrm{m}^{2} \mathrm{~h}$ in the MF and UF membranes, respectively. As shown in Table 3, by increasing effluent turbidity at high HRT levels (12 h rather than HRTs 4 and $8 \mathrm{~h}$ ), $J_{\text {Feed }}$ was decreased significantly for MF and UF membranes, so it can be concluded that fouling was enhanced. From Fig. 3a, c, it was concluded that the flux value is changed significantly when effluent 


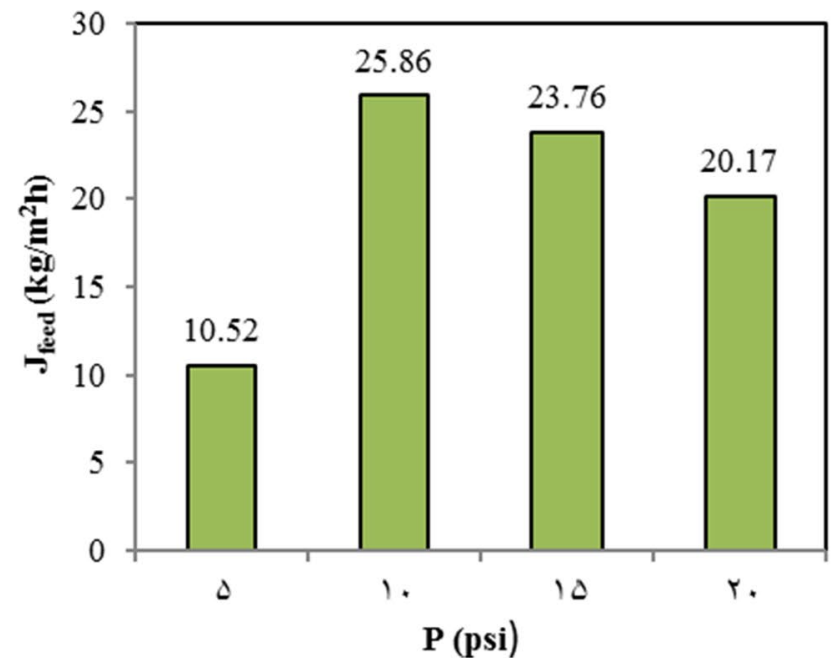

(a)

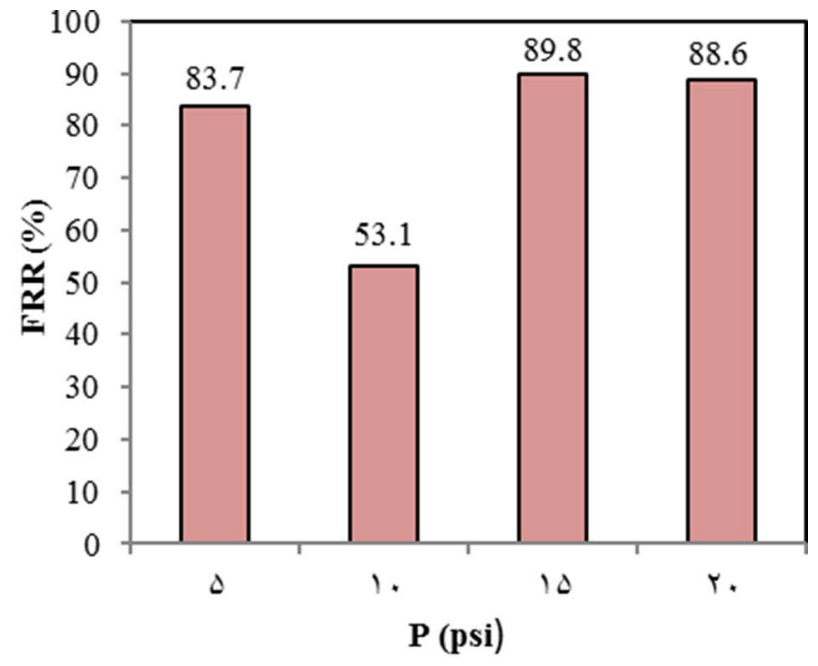

(b)

Fig. $6 J_{\text {Feed }}(\mathbf{a})$ and FRR (b) measured for MF membrane at different pressures for soft drink wastewater $(\mathrm{HRT}=12 \mathrm{~h})$

turbidity increased from $70.2 \mathrm{NTU}$ at $\mathrm{HRT}=8 \mathrm{~h}$ to $110 \mathrm{NTU}$ at $\mathrm{HRT}=12 \mathrm{~h}$. But in both HRT $=4$ and $8 \mathrm{~h}$, effluent turbidity is almost same. The more favorable COD removal efficiency was reported at HRT of $8 \mathrm{~h}$ ("COD removal" section). It should be mentioned that $\mathrm{BOD}_{5} / \mathrm{COD}$ is 0.63 for this wastewater which indicates an acceptable biodegradability. At HRT levels lower and higher than $8 \mathrm{~h}$, COD removal efficiency was decreased. At HRT levels lower than $8 \mathrm{~h}$, OLR was relatively high, while at HRTs higher than $8 \mathrm{~h}$, the system experienced longer famine phase which caused an increase in releasing SMP and finally enhanced membrane fouling. Therefore, from Table 3 and Fig. 3, HRT $=8 \mathrm{~h}$ with appropriate COD removal efficiency, low effluent turbidity and relatively better FRR and $J_{\text {Feed }}$ was considered as optimal run for pineapple fruit juice wastewater in both MF and UF membranes.

\section{- Amoxicillin wastewater}

As can be seen in Table 3 and Fig. 4a, c, the effluent turbidity was in the range of 104-124 NTU, indicating almost similar performance of the bioreactor at different conditions which caused a narrow range of $J_{\text {Feed }}, 42.5-57.3 \mathrm{~kg} / \mathrm{m}^{2} \mathrm{~h}$ and $37.3-51.1 \mathrm{~kg} / \mathrm{m}^{2} \mathrm{~h}$, for MF and UF membranes, respectively. As the effluent COD concentration was high at HRT of $4 \mathrm{~h}$ rather than other HRT levels $(655 \mathrm{mg} / \mathrm{l}$ corresponding $34 \%$ of COD removal efficiency), the minimum FRR (55\%) was obtained in this condition for the UF membrane. In contrast, the highest FRR (78.2\%) was obtained at HRT of $16 \mathrm{~h}$ with the lowest effluent COD concentration $(57 \mathrm{mg} / \mathrm{l})$. This showed that membrane fouling is significant at the lowest HRT. This can be explained by the high velocity of blocking materials toward the membrane surface at low HRTs (Barrios-Martinez et al. 2006). These materials are then absorbed by the membrane, and hence, fouling occurs earlier. In a similar work that MBRs were operated for treating municipal wastewater, it was reported that a difference in $F / M$ causes a difference in the nature of foulants. High $F / M$ ratios would change the nature of the foulant to more proteinaceous, which might be related to more severe fouling (Kimura et al. 2005). So, the lowest FRR for UF membrane observed in Fig. 4d is related to the highest $F / M$ ratio $\left(0.81 \mathrm{~d}^{-1}\right)$ which can be attributed to the proteinaceous nature of the foulant.

Therefore, from Table 3 and Fig. 4, HRT value of $16 \mathrm{~h}$ with the highest FRR (48 and 78.2\% in MF and UF, respectively) and COD removal efficiency (94.5\%) was considered as optimal run for amoxicillin wastewater in both MF and UF membranes.

\section{The effect of operating pressure on membrane fouling}

In order to investigate the effect of operating pressure on membrane fouling, the performance of two membranes (commercial MF and synthesized UF membranes) was examined at different operating pressures for treatment of three wastewaters at optimal HRTs. Feed flux $\left(J_{\text {feed }}\right)$ during $60 \mathrm{~min}$ and flux recovery ratio (FRR) were measured and calculated as the response to assess the function of the membranes at different conditions. The results are shown in Figs. 5, 6, 7 and 8.

From the results obtained for the MF membranes, the flux showed an increasing trend with an increase in pressure from 5 to 15 psi which was due to higher permeation of the membrane at the enhanced driving force provided by the pressure. However, further increase in the pressure to 20 psi caused a slight decrease in the response which can be attributed to 


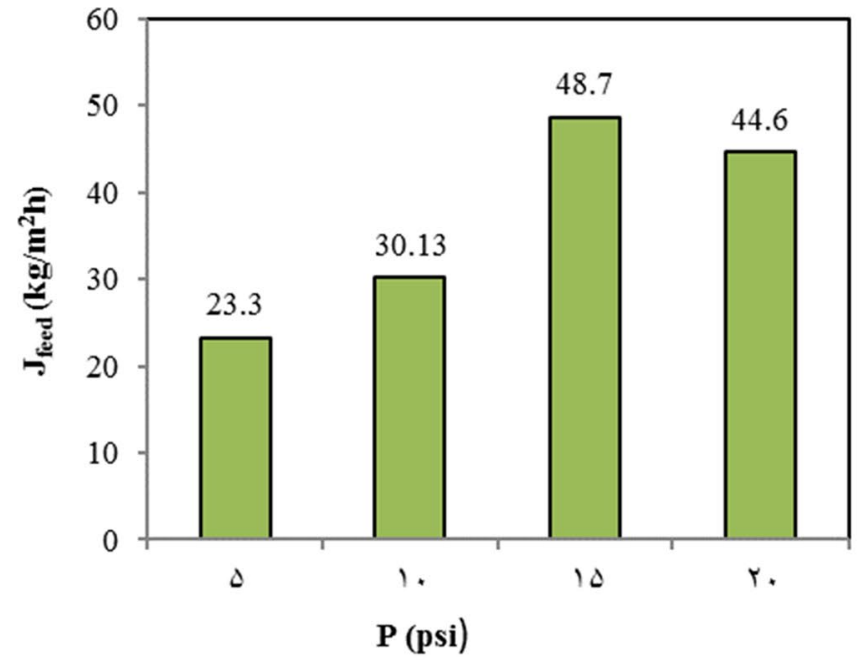

(a)

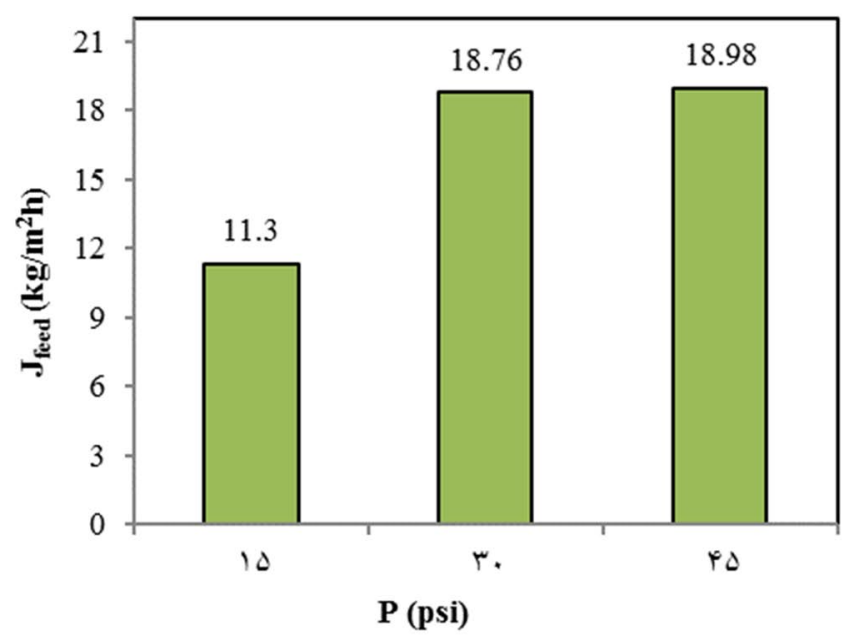

(c)

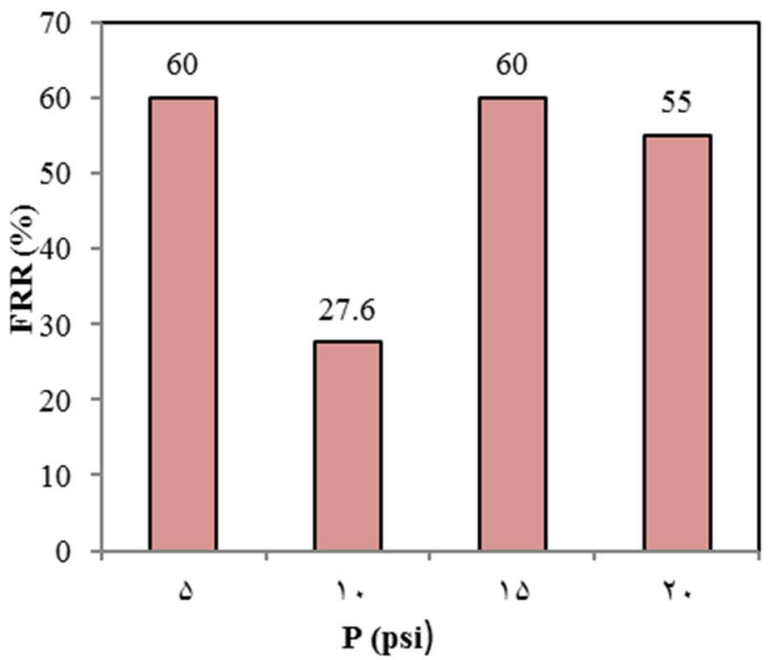

(b)

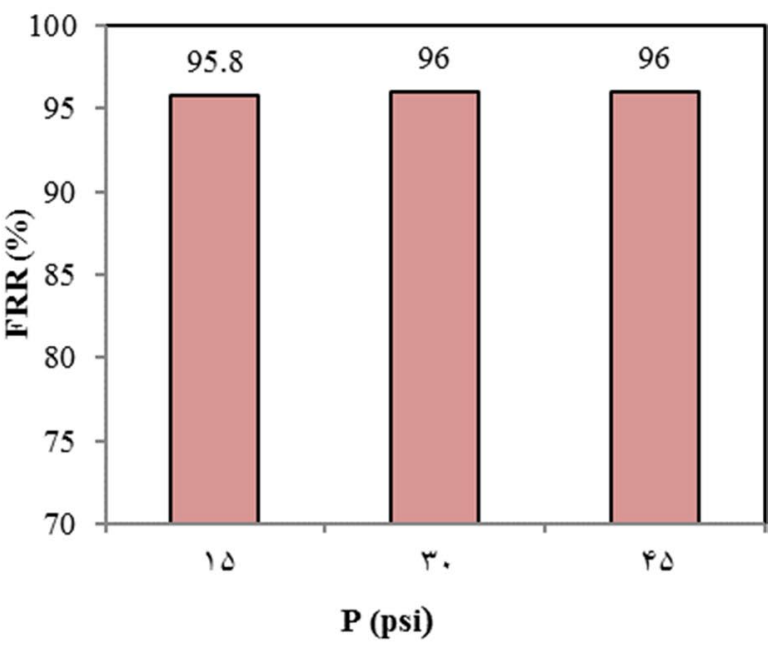

(d)

Fig. $7 J_{\text {Feed }}(\mathbf{a})$ and FRR (b) measured for MF membrane and $J_{\text {feed }}(\mathbf{c})$ and FRR (d) measured for UF membrane at different pressures for pineapple fruit juice wastewater $(\mathrm{HRT}=8 \mathrm{~h})$

concentration polarization that occurs faster at high driving force (Lee et al. 1984).

To assess irreversible fouling in the MF membrane, FRR for different pressure conditions and wastewaters is presented in Figs. 5, 6, 7 and 8b. From the results, a significant decrease in FRR obtained when pressure increased from 5 to $10 \mathrm{psi}$ for all wastewaters. This may be justified by pollutants penetration into membrane pores which increased irreversible fouling, whereas increase in the pressure from 10 to 15 psi improved FRR remarkably.

Based on the obtained results of FRR, 10 psi was not favored pressure. The lower and higher pressure values resulted in better FRR. As a fact, at pressure values lower than $10 \mathrm{psi}$, tiny particles were not forced to penetrate to membrane porosities, resulting in higher FRR value, while higher pressure values ( $\geq 10 \mathrm{psi}$ ) caused the formation of cake layer rapidly on the surface of membrane which this cake layer acts as a protective barrier to penetrate tiny particle and finally an increase in FRR was observed.

As a result, 15 psi pressure was found as the optimal operating pressure for MF membrane. In parallel, the synthesized UF membrane was tested under different operating pressures and the results were almost similar to those obtained for the MF membrane. From the results presented for $J_{\text {feed }}$ and FRR in Figs. 5, 6, 7 and 8c, d, maximum flux and FRR were obtained at 30 psi for wastewaters.

Table 4 summarizes the quality of filtered effluent in terms of COD and turbidity. From the results, soluble chemical oxygen demand (sCOD) removal efficiency was not influenced by MF and UF filtration and SCOD concentration for the filtered effluent was almost similar to the centrifuged 


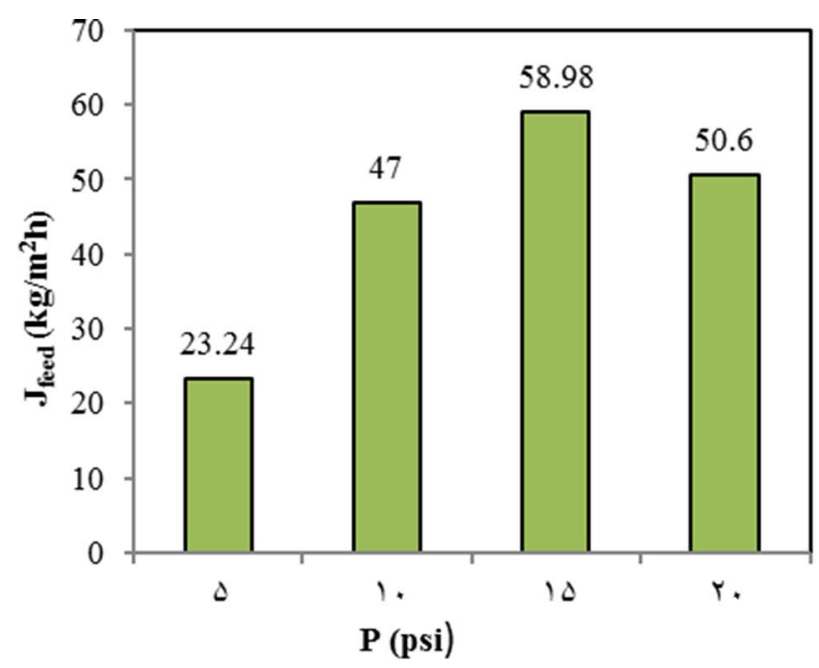

(a)

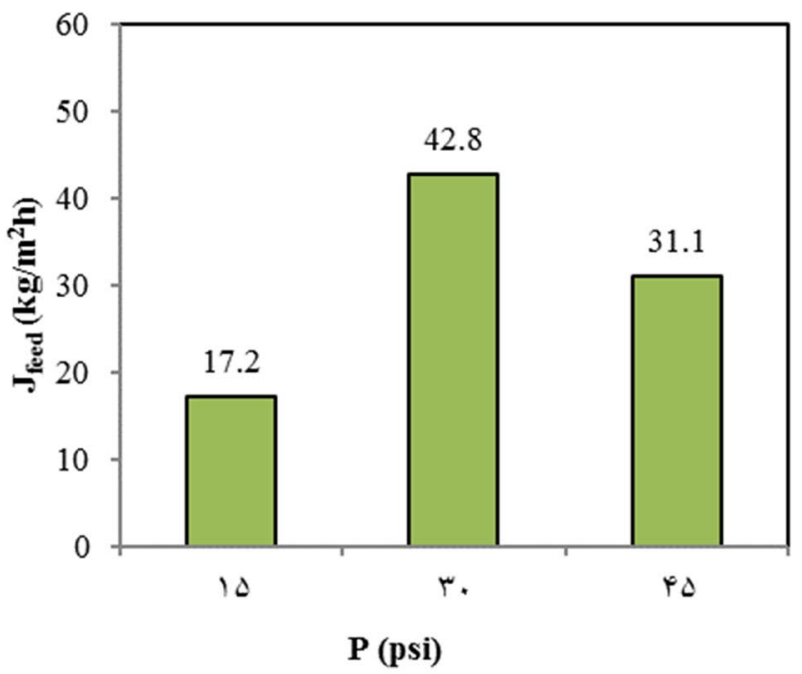

(c)

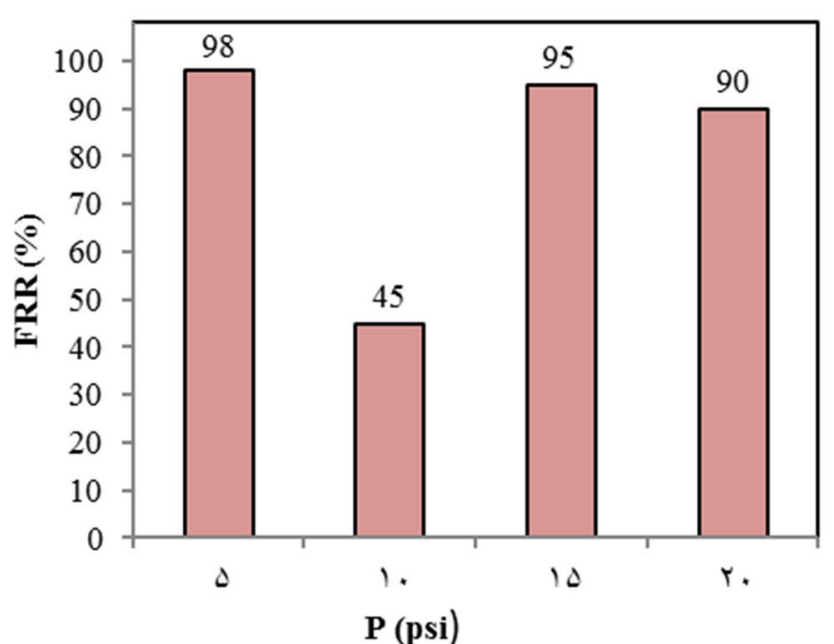

(b)

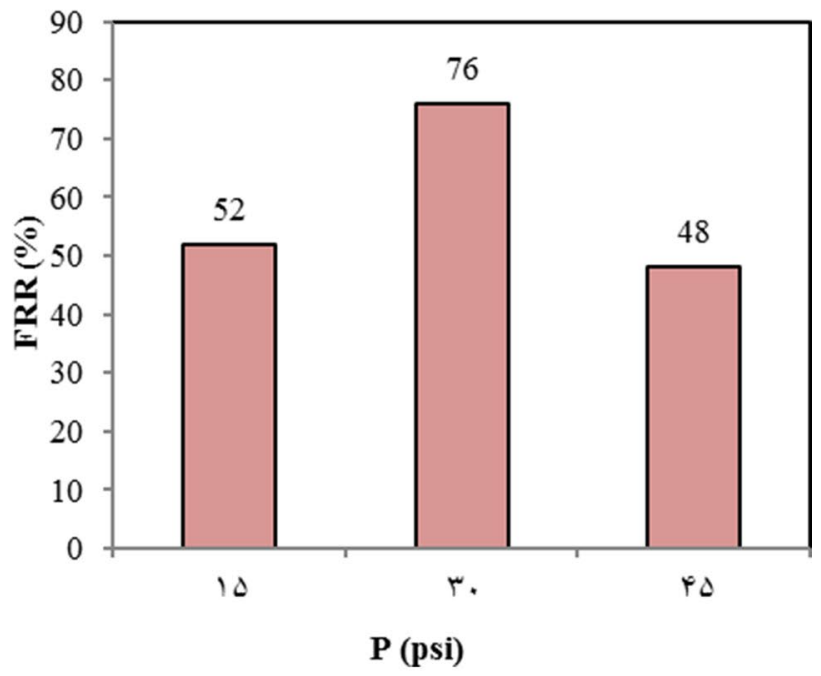

(d)

Fig. $8 J_{\text {Feed }}(\mathbf{a})$ and FRR (b) measured for MF membrane and $J_{\text {feed }}(\mathbf{c})$ and FRR (d) measured for UF membrane at different pressures for amoxicillin wastewater $(\mathrm{HRT}=16 \mathrm{~h})$

Table 4 COD and turbidity in the different conditions for the optimal runs

\begin{tabular}{|c|c|c|c|c|c|c|c|c|}
\hline \multirow[t]{2}{*}{ Type of wastewater } & \multicolumn{2}{|c|}{$\begin{array}{l}\text { Effluent after set- } \\
\text { tling tank }\end{array}$} & \multicolumn{2}{|c|}{ Centrifuged effluent } & \multicolumn{2}{|c|}{$\begin{array}{l}\text { Effluent filtered by MF } \\
\text { membrane at } 15 \mathrm{psi}\end{array}$} & \multicolumn{2}{|c|}{$\begin{array}{l}\text { Effluent filtered by UF } \\
\text { membrane at } 30 \mathrm{psi}\end{array}$} \\
\hline & TCOD & Turbidity & TCOD & Turbidity & TCOD & Turbidity & TCOD & Turbidity \\
\hline Soft drink wastewater at $\mathrm{HRT}=4 \mathrm{~h}$ & 48.7 & 38.6 & 40.7 & 4.6 & 40.4 & No detectable & 40.4 & No detectable \\
\hline Soft drink wastewater at HRT $=12 \mathrm{~h}$ & 110.9 & 77.1 & 90.7 & 6.65 & 88.4 & No detectable & 88 & No detectable \\
\hline Pineapple fruit juice at wastewater at $\mathrm{HRT}=8 \mathrm{~h}$ & 212.7 & 70.2 & 210 & 4.81 & 210 & No detectable & 210 & No detectable \\
\hline Amoxicillin wastewater at $\mathrm{HRT}=16 \mathrm{~h}$ & 57 & 116 & 47.3 & 14.7 & 46 & No detectable & 45.8 & No detectable \\
\hline
\end{tabular}

sample. In contrast, turbidity was decreased with applying MF and UF membranes relative to the centrifuged sample.
Long-term performance of the MF and modified UF membranes used for different wastewaters 
Fig. 9 The results of $J_{\text {feed }}$ during long-term filtration in the MF membrane at constant pressure of 15 psi for three types of wastewater

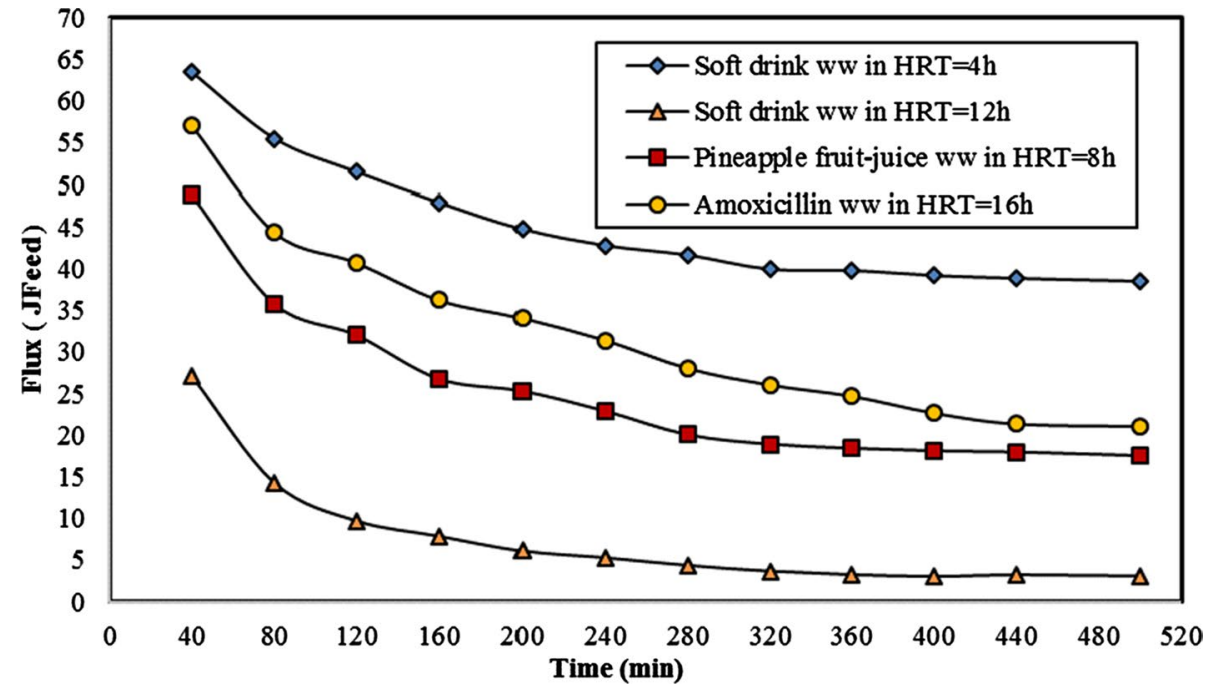

Fig. 10 The results of $J_{\text {feed }}$ during long-term filtration in the UF membrane at constant pressure of 30 psi for three types of wastewater

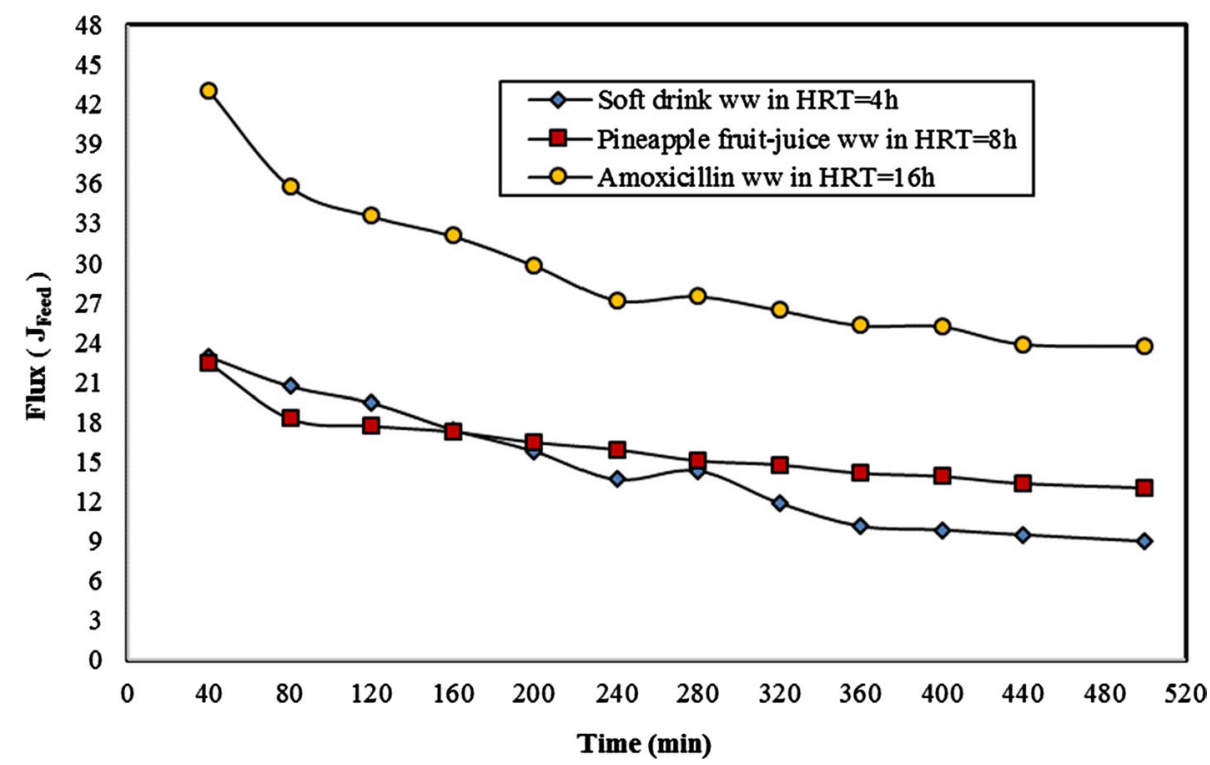

Table 5 The results of FRR\% and FR\% during long-term filtration in the MF membrane at constant pressure of 15 psi for three types of wastewater

\begin{tabular}{lllll}
\hline & $\begin{array}{l}\text { Soft drink ww } \\
\text { in HRT=4 h }\end{array}$ & $\begin{array}{l}\text { Soft drink ww } \\
\text { in HRT=12 h }\end{array}$ & $\begin{array}{l}\text { Pineapple } \\
\text { fruit juice ww } \\
\text { in HRT =8 h }\end{array}$ & $\begin{array}{l}\text { Amoxicil- } \\
\text { lin ww in } \\
\text { HRT =16 h }\end{array}$ \\
\hline FR\% & 60.7 & 11.3 & 35.9 & 36.8 \\
FRR\% & 87 & 87 & 25.3 & 36 \\
\hline
\end{tabular}

In our study, the supernatant of settling tank was passed through membranes. As wash out of microorganisms at high concentration of MLSS is considerable, therefore, very thin cake layer on membrane surface can be formed.

In this stage, to investigate the effect of cake formation on membrane fouling during treatment of different
Table 6 The results of FRR\% and FR\% during long-term filtration in the UF membrane at constant pressure of 30 psi for three types of wastewater

\begin{tabular}{llll}
\hline & $\begin{array}{l}\text { Soft drink ww in } \\
\text { HRT }=4 \mathrm{~h}\end{array}$ & $\begin{array}{l}\text { Pineapple fruit juice } \\
\text { ww in HRT }=8 \mathrm{~h}\end{array}$ & $\begin{array}{l}\text { Amoxicil- } \\
\text { lin ww in } \\
\text { HRT }=16 \mathrm{~h}\end{array}$ \\
\hline FR\% & 39.1 & 57.8 & 55 \\
FRR\% & 71 & 91.1 & 58 \\
\hline
\end{tabular}

wastewaters, a long-term experiment (500 $\mathrm{min}$ ) with the bioreactor effluent was carried out in the dead-end setup at adjusted pressure of 15 and 30 psi for MF and UF membranes, respectively. Due to high wash out of microorganisms in the bioreactor, this time was sufficient to thin layer cake formation on membrane surface. Also, the variations 
Fig. 11 The results of $J_{\text {feed }}$ during intermittent filtration of MF membrane at constant pressure of 15 psi for three types of wastewater

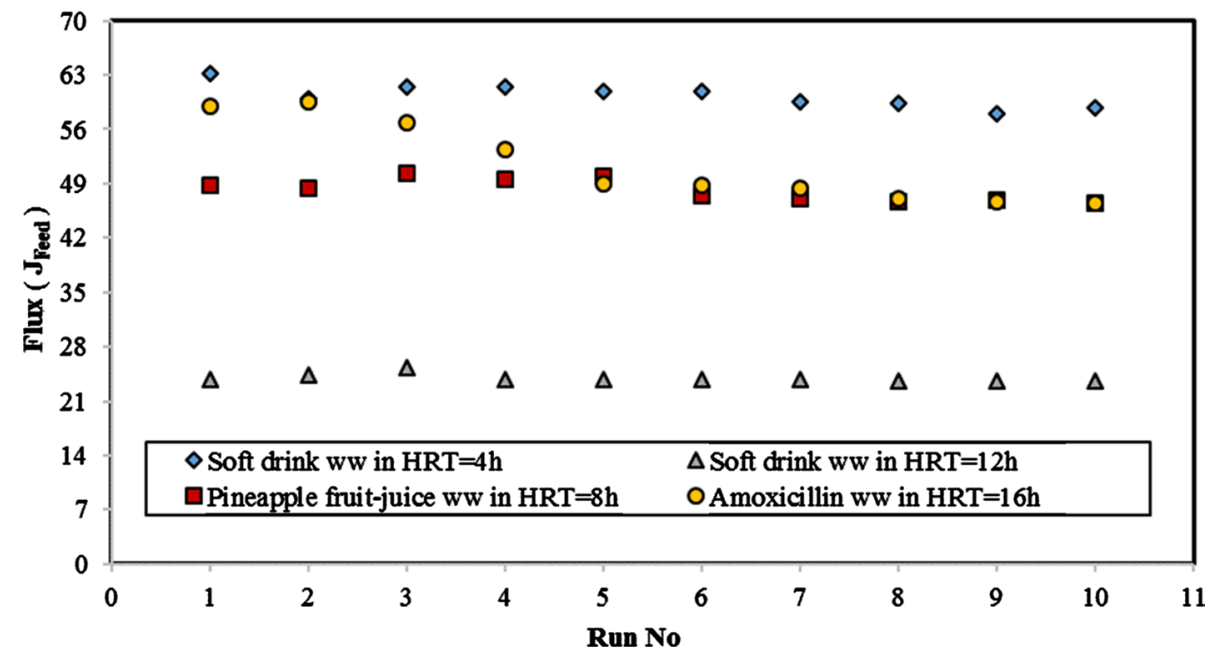

Fig. 12 The results of $J_{\text {feed }}$ during intermittent filtration of UF membrane at constant pressure of $30 \mathrm{psi}$ for three types of wastewater

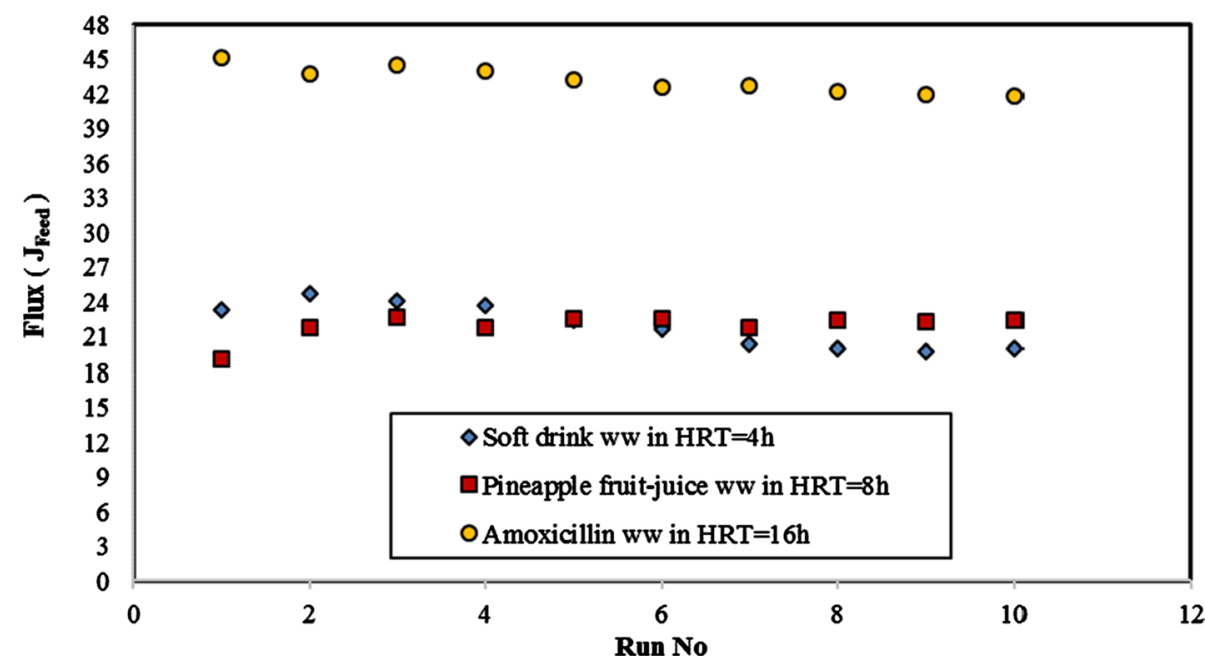

of flux through membranes $\left(J_{\text {Feed }}\right)$ as a function of time are depicted in Figs. 9 and 10. The flux is first decreased with an increase in time and finally become constant, leading to a time-independent filtration. The results of flux reduction percent $(\mathrm{FR} \%)$ and flux recovery ratio (FRR) are presented in Tables 5 and 6. As shown in Fig. 9 and Table 5, for MF membrane, the highest flux decline for soft drink wastewater was observed at HRT of $4 \mathrm{~h}$ (FR\% of 60.7), while the lowest reduction in the flux for the soft drink wastewater was obtained at HRT of $12 \mathrm{~h}(\mathrm{FR} \%=11.3)$. The results showed that FRR for pineapple fruit juice wastewater was severely decreased. The higher FRR indicates the better antifouling property for the membrane. The FRR for the pineapple fruit juice wastewater at HRT of $8 \mathrm{~h}(25.3 \%)$ was lower than the FRR obtained for other wastewaters. In the best case, the flux recovery percentage for soft drink wastewater at both HRT of 4 and $12 \mathrm{~h}$ was $87 \%$. The flux profiles for all runs showed the same trend of flux decrease with time. The decrease in the flux during membrane operation is commonly attributed to the thin cake layer formation on the membrane surface. Under the similar operating conditions with the same type of membrane materials, the fouling values are correlated with different biomass characteristics in membrane fouling. The total membrane resistance increased thereafter, likely due to cake formation and biofouling (Chang et al. 2002).

Figure 10 shows typical flux versus time profiles for the modified UF membrane. The flux for all runs declined with operating time due to membrane fouling. From Table 6, the highest flux decline and FRR for the pineapple fruit juice wastewater were observed at HRT of $8 \mathrm{~h}(\mathrm{FR}=57.8 \%$ and FRR $=91.1 \%$ ). In both MF and UF membranes, the flux declined very rapidly in the first $40 \mathrm{~min}$ of the batch filtration tests. The initial sharp decline in permeate flux was mainly because of pore clogging and cake layer formation on the membrane surface. The drastic reduction in permeate flux might be caused by EPS that filled the void spaces between the cell particles in the cake layer (Hong et al. 2002). 


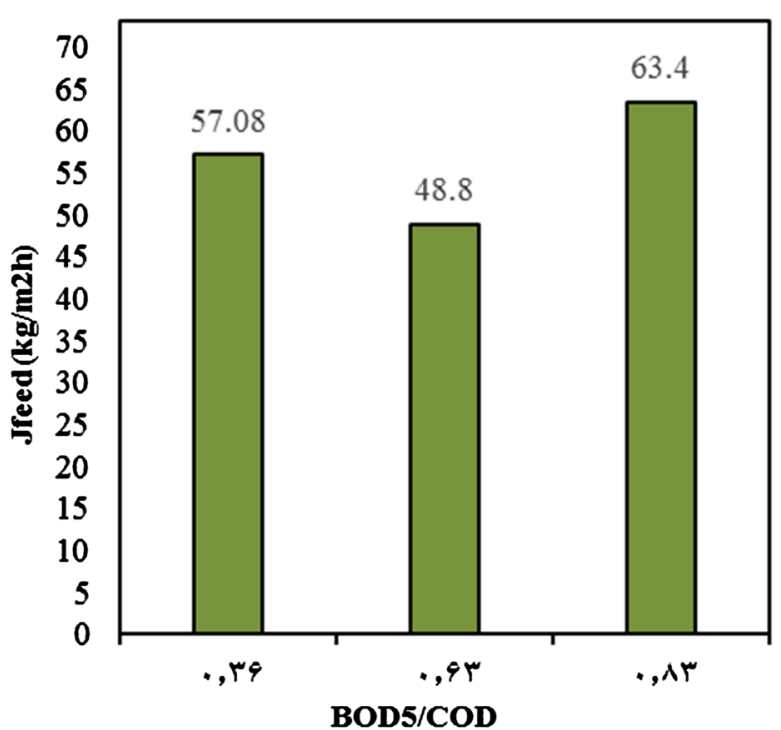

(a)

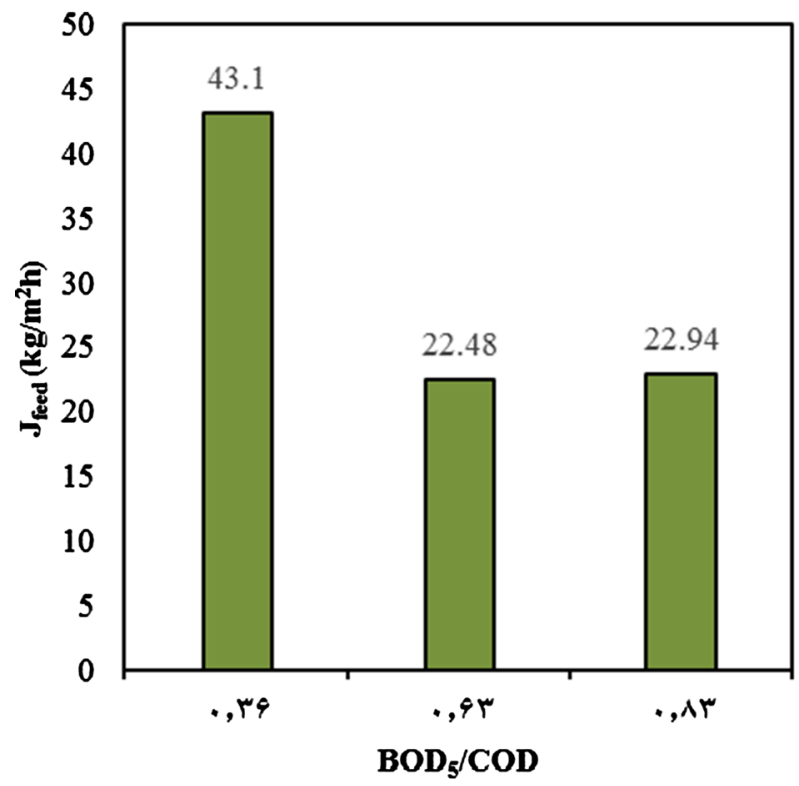

(c)

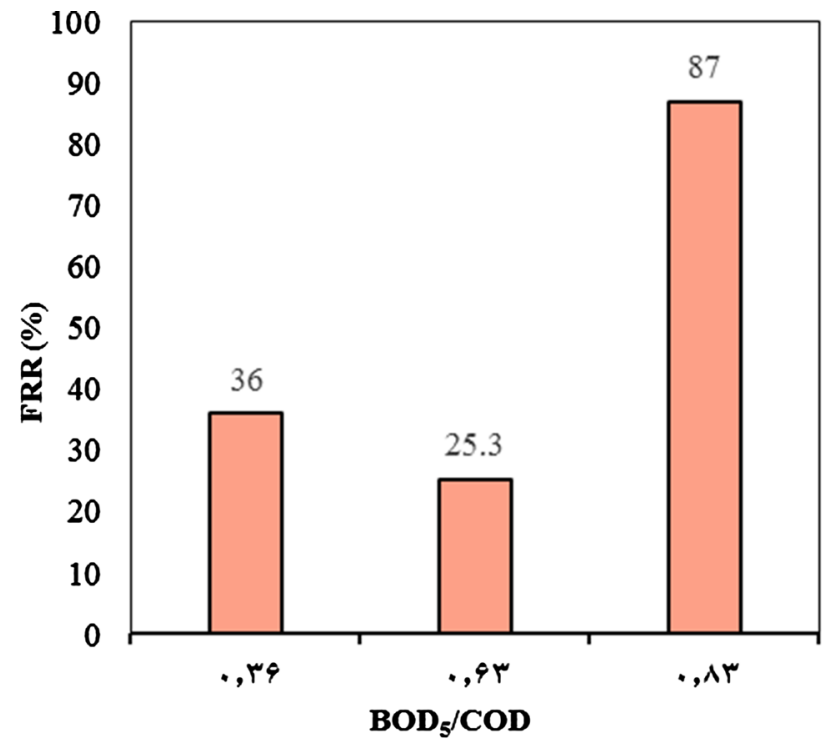

(b)

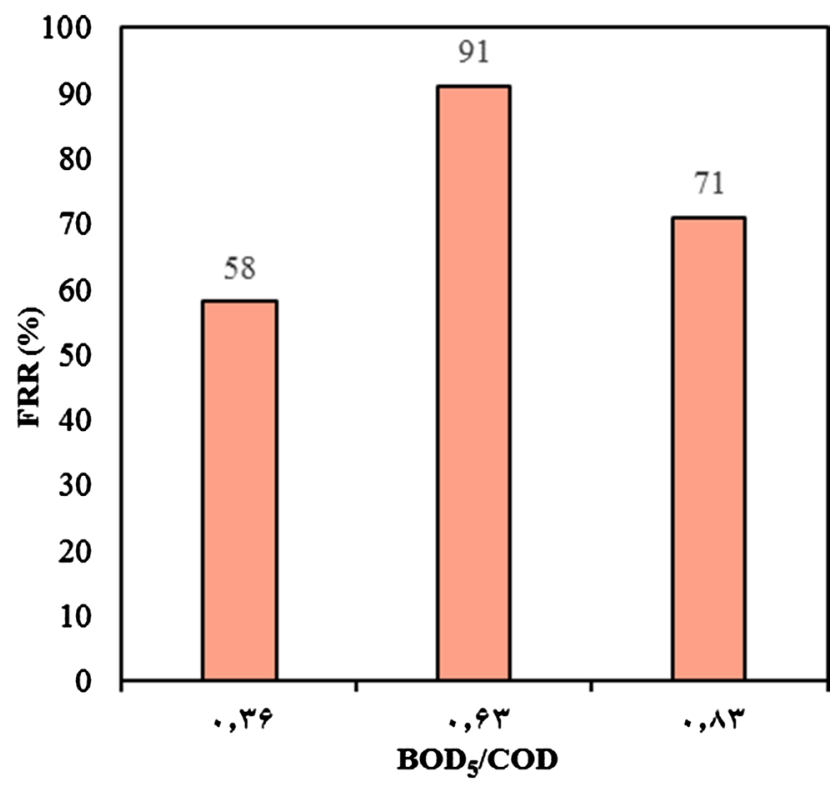

(d)

Fig. $13 J_{\text {Feed }}\left(\right.$ a) and FRR (b) measured for MF membrane at pressures of 15 psi and $J_{\text {feed }}(\mathbf{c})$ and FRR (d) measured for UF membrane at pressures of 30 psi for type of wastewater

The cross-flow module is the approach which is practiced in industry for the membrane filtration. In this method, the shear stress applied by the cross-flow regime avoids biofilm accumulation on the membrane surface. Therefore, in this stage, in order to stimulate the same condition in the dead-end system, the membrane was intermittently washed by pure water during a long-term filtration. The variations of flux $\left(J_{\text {Feed }}\right)$ are depicted in Figs. 11 and 12. From the figures, the changes in the flux were not significant for different wastewaters in both MF and UF membranes.

As a conclusion on the effect of wastewater type on the performance of the MF and UF membranes, $J_{\text {feed }}$ and FRR data at the optimum conditions for different wastewaters are compared in Fig. 13.

As can be seen in Fig. 13a, c, pineapple fruit juice wastewater has shown the lowest flux compared to the other wastewaters. The presence of some minerals such as $\mathrm{Zn}$, As, 
Table 7 FRR and $J_{\text {Feed }}$ measured for MF and UF membranes for type of wastewater

\begin{tabular}{lllll}
\hline $\begin{array}{l}\text { Type of waste- } \\
\text { water }\end{array}$ & $\begin{array}{l}\text { Type of } \\
\text { mem- } \\
\text { brane }\end{array}$ & Pressure, psi & FRR (\%) & $J_{\text {feed }}\left(\mathrm{kg} / \mathrm{m}^{2} \mathrm{~h}\right)$ \\
\hline Soft drink & MF & 15 & 87 & 63.4 \\
& UF & 30 & 71 & 22.94 \\
Pineapple fruit & MF & 15 & 25.3 & 48.8 \\
juice & UF & 30 & 91.1 & 22.48 \\
Amoxicillin & MF & 15 & 36 & 58.08 \\
& UF & 30 & 58 & 43.1 \\
\hline
\end{tabular}

$\mathrm{Mg}, \mathrm{Na}, \mathrm{P}, \mathrm{K}$ and $\mathrm{Al}$ in pineapple juice has been reported by Sairi et al. (2004). Some cations can participate in biological precipitation and contribute to inorganic fouling. This could be result in more integrated sludge and fouling effect (Costa et al. 2006). However, FRR in UF membrane for pineapple fruit juice wastewater is highly relative to soft drink and amoxicillin wastewaters. The reason that can be given is that the particles present in pineapple fruit juice wastewater are smaller than MF membrane pores and can penetrate into the membrane pores and cause a considerable drop in FRR in the MF, while there was no any adverse impact on FRR in the UF.

From Fig. 13a, b, soft drink wastewater had the maximum feed flux $\left(J_{\text {feed }}\right)$ and FRR. It might be attributed to low turbidity of the feed and not interactive SMP with MF membrane composition, whereas this wastewater showed a lower $J_{\text {feed }}$ and FRR in the UF membrane, implying an effective interaction between the residual SMP and the UF membrane composition.

Table 7 summarizes the results for MF and UF membranes with different wastewaters composition. As a conclusion, both membranes (commercial MF and synthesized UF membranes) showed the same performance in terms of COD removal efficiency and effluent turbidity (Table 4). But, in terms of membrane performance parameters (flux and FRR), MF membrane showed better performance for soft drink wastewater due to higher $J_{\text {feed }}$ and FRR at lower operating pressure (15 psi) compared to the UF membrane. For pineapple fruit juice wastewater, despite the prepared UF membrane had lower $J_{\text {feed }}$ at higher operating pressure relative to the MF membrane, it is preferred for pineapple fruit juice wastewater due to its remarkable high FRR which is along with less operational cost for the membrane cleaning. Both membranes showed almost same performance for amoxicillin wastewater.

\section{Conclusion}

Three wastewaters with different $\mathrm{BOD}_{5} / \mathrm{COD}$ ratios (soft drink (0.83), pineapple fruit juice (0.63) and amoxicillin (0.36)) were successfully treated in AS-MP system. The optimal HRT obtained for soft drink, pineapple fruit juice and amoxicillin wastewaters was 4,8 and $16 \mathrm{~h}$, respectively. According to the obtained data of FRR and $J_{\text {feed }}, 15$ and 30 psi were found as the optimal operating pressure for MF and UF membranes, respectively. From the results, sCOD removal efficiency was not influenced by MF and UF filtration, while turbidity was decreased with applying MF and UF membranes. As a conclusion, both membranes (commercial MF and synthesized UF membranes) showed the same performance in terms of COD removal efficiency and effluent turbidity. But, in terms of membrane performance parameters (flux and FRR), MF membrane showed better performance for soft drink wastewater due to higher $J_{\text {feed }}$ and FRR obtained at lower operating pressure (15 psi) compared to the UF membrane. For pineapple fruit juice wastewater, despite the prepared UF membrane had lower $J_{\text {feed }}$ at higher operating pressure relative to the MF membrane, it is preferred for pineapple fruit juice wastewater due to its remarkable high FRR which is along with less operational cost for the membrane cleaning. Both membranes showed almost same performance for amoxicillin wastewater.

\section{Compliance with ethical standards}

Conflict of interest The authors declare that they have no conflict of interest.

Open Access This article is licensed under a Creative Commons Attribution 4.0 International License, which permits use, sharing, adaptation, distribution and reproduction in any medium or format, as long as you give appropriate credit to the original author(s) and the source, provide a link to the Creative Commons licence, and indicate if changes were made. The images or other third party material in this article are included in the article's Creative Commons licence, unless indicated otherwise in a credit line to the material. If material is not included in the article's Creative Commons licence and your intended use is not permitted by statutory regulation or exceeds the permitted use, you will need to obtain permission directly from the copyright holder. To view a copy of this licence, visit http://creativecommons.org/licenses/by/4.0/.

\section{References}

Abbasi S, Mirghorayshi M, Zinadini S, Zinatizadeh AA (2020) Novel single continuous electrocoagulation process for treatment of licorice processing wastewater: optimization of operating factors using RSM. Process Saf Environ Prot 134:323-332

Abou-Elela SI, El-Khateeb MA (2015) Performance evaluation of activated sludge process for treating pharmaceutical wastewater contaminated with $\beta$-lactam antibiotics. J Ind Pollut Cont 31(1):1-5

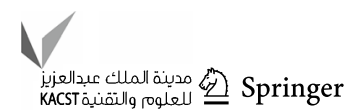


American Public Health Association (APHA) (1999) Standard methods for the examination of water and wastewater, New York

Amini M, Younesi H, Zinatizadeh AA, Najafpour G (2013) Determination of optimum conditions for dairy wastewater treatment in UAASB reactor for removal of nutrients. Bioresour Technol 145:71-79

Amor C, Lucas MS, Pirra AJ, Peres JA (2012) Treatment of concentrated fruit juice wastewater by the combination of biological and chemical processes. J Environ Sci Health Part A 47(12):1809-1817

Arabi S, Nakhla G (2008) Impact of protein/carbohydrate ratio in the feed wastewater on the membrane fouling in membrane bioreactors. J Membr Sci 324(1):142-150

Asadi A, Zinatizadeh AA, Isa MH (2012a) Performance of intermittently aerated up-flow sludge bed reactor and sequencing batch reactor treating industrial estate wastewater: a comparative study. Bioresour Technol 123:495-506

Asadi A, Zinatizadeh A, Sumathi S (2012b) Simultaneous removal of carbon and nutrients from an industrial estate wastewater in a single up-flow aerobic/anoxic sludge bed (UAASB) bioreactor. Water Res 46(15):4587-4598

Bae T-H, Tak T-M (2005) Effect of TiO2 nanoparticles on fouling mitigation of ultrafiltration membranes for activated sludge filtration. J Membr Sci 249(1):1-8

Barker DJ, Stuckey DC (1999) A review of soluble microbial products (SMP) in wastewater treatment systems. Water Res 33(14):3063-3082

Barrios-Martinez A, Barbot E, Marrot B, Moulin P, Roche N (2006) Degradation of synthetic phenol-containing wastewaters by MBR. J Membr Sci 281(1):288-296

Birjandi N, Younesi H, Bahramifar H, Ghafari S, Zinatizadeh AA, Sumathi S (2013) Optimization of coagulation-flocculation treatment on paper-recycling wastewater: application of response surface methodology. J Environ Sci Health-Part A 48:1573-1582

Chang I-S, Le Clech P, Jefferson B, Judd S (2002) Membrane fouling in membrane bioreactors for wastewater treatment. J Environ Eng 128(11):1018-1029

Charmot-Charbonnel M-L, Ripoche G, Roche N, Prost C (1999) Modeling and simulation of activated sludge process with cyclic feeding for treatment of highly loaded wastewater. Chem Eng Technol 22(1):50-56

Cicek N, Macomber J, Davel J, Suidan M, Audic J, Genestet P (2001) Effect of solids retention time on the performance and biological characteristics of a membrane bioreactor. Water Sci Technol 43(11):43-50

Costa AR, de Pinho MN, Elimelech M (2006) Mechanisms of colloidal natural organic matter fouling in ultrafiltration. J Membr Sci 281(1):716-725

Dufresne R, Lebrun R, Lavallee H (1997) Comparative-study on fluxes and performances during paper-mill waste-water treatment with membrane bioreactor. Can J Chem Eng 75(1):95-103

Fane A, Yeo A, Law A, Parameshwaran K, Wicaksana F, Chen V (2005) Low pressure membrane processes $\sim$ doing more with less energy. Desalination 185(1):159-165

Gholami F, Zinadini S, Zinatizadeh AA, Abbasi AR (2018) MU-5 metal-organic frameworks (MOFs) as a novel nanofiller for flux increment and fouling mitigation in PES ultrafiltration membrane. Sep Purif Technol 194:272-280

Grady C, Daigger G, Lim H (1999) Biological wastewater treatment. Marcel Dekker Inc, New York

Ho W, Sirkar K (2012) Membrane handbook. Springer, Berlin

Hong S, Bae T, Tak T, Hong S, Randall A (2002) Fouling control in activated sludge submerged hollow fiber membrane bioreactors. Desalination 143(3):219-228
Inadini S, Zinatizadeh A, Rahimi M, Vatanpour V (2017) Magnetic field-augmented coagulation bath during phase inversion for preparation of $\mathrm{ZnFe} 2 \mathrm{O} 4 / \mathrm{SiO} 2 / \mathrm{PES}$ nanofiltration membrane: a novel method for flux enhancement and fouling resistance. J Ind Eng Chem 46:9-18

Isma MA, Idris A, Omar R, Razreena AP (2014) Effects of SRT and HRT on treatment performance of MBR and membrane fouling. Int J Chem Mol Nucl Mater Metall Eng 8(6):451-455

Kim IS, Jang N (2006) The effect of calcium on the membrane biofouling in the membrane bioreactor (MBR). Water Res 40(14):2756-2764

Kimura K, Yamato N, Yamamura H, Watanabe Y (2005) Membrane fouling in pilot-scale membrane bioreactors (MBRs) treating municipal wastewater. Environ Sci Technol 39(16):6293-6299

Laspidou CS, Rittmann BE (2002) A unified theory for extracellular polymeric substances, soluble microbial products, and active and inert biomass. Water Res 36(11):2711-2720

Le-Clech P, Chen V, Fane TA (2006) Fouling in membrane bioreactors used in wastewater treatment. J Membr Sci 284(1):17-53

Lee S, Aurelle Y, Roques H (1984) Concentration polarization, membrane fouling and cleaning in ultrafiltration of soluble oil. $\mathrm{J}$ Membr Sci 19(1):23-38

Li X, Gao F, Hua Z, Du G, Chen J (2005) Treatment of synthetic wastewater by a novel MBR with granular sludge developed for controlling membrane fouling. Sep Purif Technol 46(1):19-25

Mansouri Y, Zinatizadeh AA, Mohammadi P, Irandoust M, Akhbari A (2012) Hydraulic characteristics analysis of an anaerobic rotatory biological contactor (AnRBC) using tracer experiments and response surface methodology (RSM), Korean. J Chem Eng 29:891-902

McAdam EJ, Judd SJ, Cartmell E, Jefferson B (2007) Influence of substrate on fouling in anoxic immersed membrane bioreactors. Water Res 41(17):3859-3867

Meng F, Shi B, Yang F, Zhang H (2007) Effect of hydraulic retention time on membrane fouling and biomass characteristics in submerged membrane bioreactors. Bioprocess Biosyst Eng 30(5):359-367

Meng F, Chae S-R, Drews A, Kraume M, Shin H-S, Yang F (2009) Recent advances in membrane bioreactors (MBRs): membrane fouling and membrane material. Water Res 43(6):1489-1512

Min K-N, Ergas SJ, Mermelstein A (2008) Impact of dissolved oxygen concentration on membrane filtering resistance and soluble organic matter characteristics in membrane bioreactors. Water Sci Technol 57(2):161-165

Morgan-Sagastume F, Allen DG (2005) Activated sludge deflocculation under temperature upshifts from 30 to $45^{\circ} \mathrm{C}$. Water Res 39(6):1061-1074

Ozbas EE, Tufekci N, Yilmaz G, Ovez S (2006) Aerobic and anaerobic treatment of fruit juice industry effluents. J Sci Ind Res 65(10):830-837

Pirsaheb M, Mesdaghinia AR, Shahtaheri SJ, Zinatizadeh AA (2009) Kinetic evaluation and process performance of a fixed film bioreactor removing phthalic acid and dimethyl phthalate. J Hazard Mater 167:500-506

Pirsaheb M, Mohamadi M, Mansouri AM, Zinatizadeh AA, Sumathi S, Sharafi K (2015) Process modeling and optimization of biological removal of carbon, nitrogen and phosphorus from hospital wastewater in a continuous feeding \& intermittent discharge (CFID) bioreactor, Korean. J Chem Eng 32:1340-1353

Radjenovic J, Matosic M, Mijatovic I, Petrovic M, Barcelo D (2008) Emerging contaminants from industrial and municipal waste. Springer, Berlin, pp 37-101

Rahimi M, Zinadini S, Zinatizadeh AA, Vatanpour V, Rajabi L, Rahimi Z (2016) Hydrophilic goethite nanoparticle as a novel antifouling agent in fabrication of nanocomposite 
polyethersulfone membrane. J Appl Polym Sci. https://doi. org/10.1002/app.43592

Rosenberger S, Laabs C, Lesjean B, Gnirss R, Amy G, Jekel M, Schrotter J-C (2006) Impact of colloidal and soluble organic material on membrane performance in membrane bioreactors for municipal wastewater treatment. Water Res 40(4):710-720

Sairi M, Yih LJ, Sarmidi MR (2004) Chemical composition and sensory analysis of fresh pineapple juice and deacidified pineapple juice using electrodialysis. Citeseer, Princeton, pp 21-25

Shahrezaei F, Mansouri F, Zinatizadeh AA, Akhbari A (2012) Photocatalytic degradation of aniline using $\mathrm{TiO} 2$ nanoparticles in a vertical circulating photocatalytic reactor. Int J Photoenergy 2012,430638

Sharafi K, Mansouri AM, Zinatizadeh AA, Pirsaheb M (2015) Adsorptive removal of methylene blue from aqueous solutions by pumice powder: process modelling and kinetic evaluation. Environ Eng Manag J 14:1067-1078

Shi H, Qian Y (2009) Industrial wastewater-types, amounts and effects in point sources of pollution: local effects and control. Department of Environmental Science and Engineering, Tsinghua University-Encyclopedia of Life Support Systems (EOLSS), Japan

Shon H, Vigneswaran S, Kandasamy J, Cho J (2011) Membrane technology for organic removal in wastewater, Encyclopedia of Life Support Systems (EOLSS)

Stephenson T, Judd S, Jefferson B, Brindle K, Association IW (2000) Membrane bioreactors for wastewater treatment. Citeseer, Princeton

Su Y, Huang C, Lee H, Pan JR (2008) Characteristics of membrane fouling in submerged membrane bioreactor under sub-critical flux operation. Water Sci Technol 57(4):601-605
Trussell RS, Merlo RP, Hermanowicz SW, Jenkins D (2006) The effect of organic loading on process performance and membrane fouling in a submerged membrane bioreactor treating municipal wastewater. Water Res 40(14):2675-2683

Trussell RS, Merlo RP, Hermanowicz SW, Jenkins D (2007) Influence of mixed liquor properties and aeration intensity on membrane fouling in a submerged membrane bioreactor at high mixed liquor suspended solids concentrations. Water Res 41(5):947-958

Yu H-Y, Hu M-X, Xu Z-K, Wang J-L, Wang S-Y (2005a) Surface modification of polypropylene microporous membranes to improve their antifouling property in MBR: NH3 plasma treatment. Sep Purif Technol 45(1):8-15

Yu H-Y, Xie Y-J, Hu M-X, Wang J-L, Wang S-Y, Xu Z-K (2005b) Surface modification of polypropylene microporous membrane to improve its antifouling property in MBR: $\mathrm{CO} 2$ plasma treatment. J Membr Sci 254(1):219-227

Zinadini S, Zinatizadeh A, Rahimi M, Vatanpour V, Zangeneh H, Beygzadeh M (2014) Novel high flux antifouling nanofiltration membranes for dye removal containing carboxymethyl chitosan coated Fe3O4 nanoparticles. Desalination 349:145-154

Zinatizadeh AA, Ibrahim S, Aghamohammadi N, Mohamed AR, Zangeneh H, Mohammadi P (2017) Polyacrylamide-induced coagulation process removing suspended solids from palm oil mill effluent. Sep Sci Technol 52:520-527

Publisher's Note Springer Nature remains neutral with regard to jurisdictional claims in published maps and institutional affiliations. 